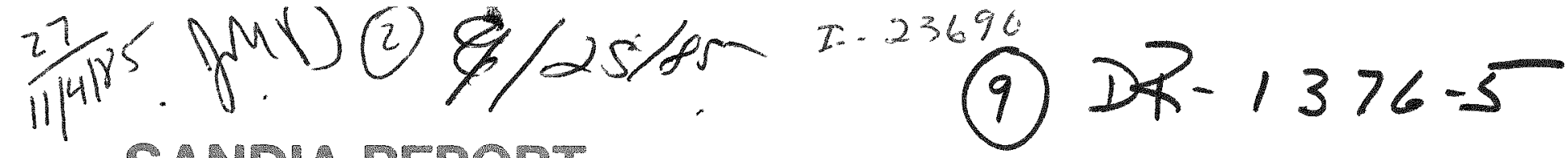
SAMDIA REPORT SAND83-0451 - Unlimited Release - UC-70

Printed September 1985

\title{
Preliminary Report on Fluid Inclusions From Halites in the Castile and Lower Salado Formations of the Delaware Basin, Southeastern New Mexico
}

Carol L. Stein

\section{Prepared by}

Sandia National Laboratories

Albuquerque, New Mexico 87185 and Livermore, California 94550

for the United States Department of Energy

under Contract DE-AC04-76DP00789 
Issued by Sandia National Laboratories, operated for the United States Department of Energy by Sandia Corporation.

NOTICE: This report was prepared as an account of work sponsored by an agency of the United States Government. Neither the United States Govern ment nor any agency thereof, nor any of their employees, nor any of their contractors, subcontractors, or their employees, makes any warranty, express or implied, or assumes any legal liability or responsibility for the accuracy, completeness, or userulness of any information, apparatus, prod uct, or process disclosed, or represents that its use would not infring privately owned rights. Reference herein to any specific commercial product process, or service by trade name, trademark, manufacturer, or otherwise, does not necessarily constitute or imply its endorsement, recommendation, or favoring by the United States Government, any agency thereof or any of their contractors or subcontractors. The views and opinions expressed herein do not necessarily state or reflect those of the United States Government any agency thereof or any of their contractors or subcontractors.

Printed in the United States of America Available from

National Technical Information Service

U.S. Department of Commerce

5285 Port Royal Road

Springfield, VA 22161

NTIS price codes

Printed copy: A0s

Microfiche copy: A01 


\section{DISCLAIMER}

This report was prepared as an account of work sponsored by an agency of the United States Government. Neither the United States Government nor any agency Thereof, nor any of their employees, makes any warranty, express or implied, or assumes any legal liability or responsibility for the accuracy, completeness, or usefulness of any information, apparatus, product, or process disclosed, or represents that its use would not infringe privately owned rights. Reference herein to any specific commercial product, process, or service by trade name, trademark, manufacturer, or otherwise does not necessarily constitute or imply its endorsement, recommendation, or favoring by the United States Government or any agency thereof. The views and opinions of authors expressed herein do not necessarily state or reflect those of the United States Government or any agency thereof. 


\section{DISCLAIMER}

Portions of this document may be illegible in electronic image products. Images are produced from the best available original document. 


\title{
Preliminary Report on Fluid Inclusions From Halites in the Castile and Lower Salado Formations of the Delaware Basin, Southeastern New Mexico
}

\author{
Carol L. Stein \\ Earth Sciences Division \\ Sandia National Laboratories \\ Albuquerque, NM 87185
}

SAND- -83-0451

DE86 002094

\begin{abstract}
A suite of samples composed primarily of halite from the upper Castile and lower Salado Formations of the Permian Basin was selected from Waste Isolation Pilot Plant (WIPP) core for a reconnaissance study of fluid inclusions. Volume percent of these trapped fluids averaged $0.7 \%$ to $1 \%$. Freezing-point depressions varied widely and appeared to be unrelated to fluid-inclusion type, to sedimentary facies, or to stratigraphic depth. However, because very low freezing points were usually associated with anhydrite, a relation may exist between freezing-point data and lithology. Dissolved sulfate values were constant through the Castile, then decreased markedly with lesser depth in the lower Salado. This trend correlates very well with observed mineralogy and is consistent with an interpretation of the occurrence of secondary polyhalite as a result of gypsum or anhydrite alteration with simultaneous consumption of dissolved sulfate from the coexisting fluids. Together with the abundance and distribution of fluid inclusions in primary or "hopper" crystal structures, this evidence suggests that inclusions seen in these halites did not migrate any significant geographical distance since their formation.
\end{abstract}




\section{Acknowledgments}

Analytical assistance was provided by D. R. Tallant and K. L. Higgins of Division 1823, who performed the laser Raman analyses, and by J. L. Krumhansl of Division 2543, who provided the emission spectroscopy results. Freezing-point measurements were made at the facility belonging to the Department of Geology, University of Texas at El Paso. The help provided there by Professor P. C. Goodell and Mr. B. Filsinger is gratefully acknowledged. The manuscript was critically reviewed by J. L. Krumhansl and D. J. Borns. In addition, I am indebted to E. Roedder (USGS-Reston) for his thorough reading of the manuscript and for his many helpful comments.

\section{DISCLAIMER}

an account of work sponsored by an agency of the United States the United States Government nor any agency thereof, nor any of their Government. Neither the United express or implied, or assumes any legal liability or responsiemployees, makes any warranty, exp bility for the accuracy, completeness, or use would not infringe privately owned rights. Referprocess disclosed, or represents that its use ence herein to any specific commercial product, procsitute or imply its endorsement, recommanufacturer, or otherwise does not necessarily constitutent or any agency thereof. The views mendation, or favoring by the United States Governmessarily state or reflect those of the

and opinions of authors expressed herel thereof. 


\section{Contents}

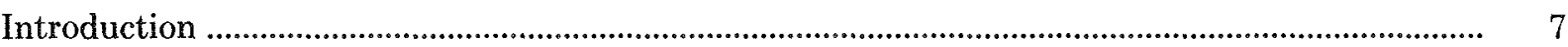

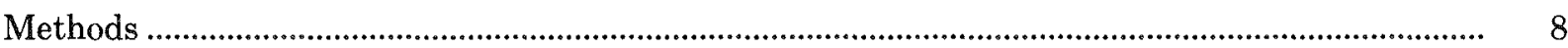

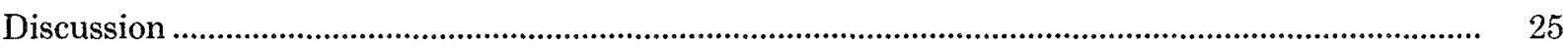

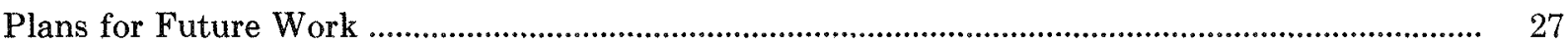

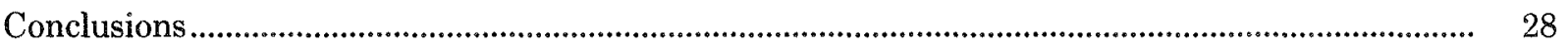

APPENDIX A-Laser Raman Spectra............................................................................................ 31

APPENDIX B-Freezing-Point Calculations in NaCl Solutions ..................................................... 37

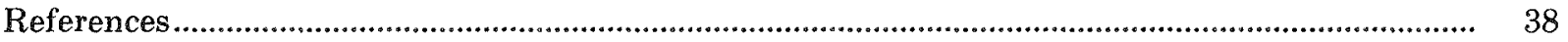

\section{Figures}

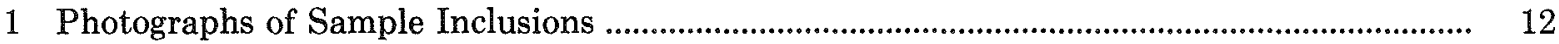

2 Sample 9-2677: <1\% Mechanical Deformation ........................................................................ 13

3 Sample 2625: This Sample, a Product of the Experimental Work of W. Wawersik, Has Undergone 7\% Deformation ................................................................................................. 14

4 Sample 2625: As Seen in Figure 3, 7\% Deformation ............................................................... 15

5 Sample of Lower Salado Formation Salt From the Level of the Facility Horizon at

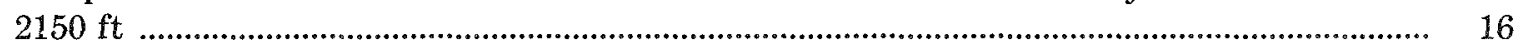

6 ERDA-6 Lithology Showing Distribution of Halite and Anhydrite ...................................... 17

7 WIPP-12 Lithology Showing Distribution of Halite and Anhydrite ...................................... 18

8 ERDA-9 Lithology Showing Distribution of Halite and Anhydrite ........................................ 19

9 DOE-1 Lithology Showing Distribution of Halite and Anhydrite ........................................... 20

10 Freezing Temperatures vs Lithology in WIPP-12 .................................................................. 21

11 Laser Raman Spectroscopic Analyses of Samples From WIPP-12 and DOE-1 ….............. 24

12 Lithology of WIPP-12 ................................................................................................................. 24

13 Plot of Fluid-Inclusion Freezing Temperatures vs Depth in the Lower Salado and Upper Castile Formations ...................................................................................................... 25

14 Composition of Delaware Basin Groundwater, $\log \left(\mathrm{Ca}^{2+}\right)$ vs $\log \left(\mathrm{SO}_{4}^{2-}\right)$............................ 28

15 Composition of Delaware Basin Groundwater, $\log \left(\mathrm{K}^{+}\right)$vs $\log \left(\mathrm{Cl}^{-}\right)$.................................. 28

16 Composition of Delaware Basin Groundwater, $\log \left(\mathrm{Mg}^{2+}\right)$ vs $\log \left(\mathrm{Cl}^{-}\right)$................................. 29

17 Composition of Delaware Basin Groundwater, $\log \left(\mathrm{Na}^{+}\right)$vs $\log \left(\mathrm{Cl}^{-}\right)$................................. 29

\section{Tables}

1 Freezing-Point Depressions .................................................................................................... 9

2 Laser Raman Spectroscopy Analyses for Dissolved Sulfate in Fluid Inclusions ................... 23 
$$
\text { . }
$$ 


\section{Preliminary Report on Fluid Inclusions From Halites in the Castile and Lower Salado Formations of the Delaware Basin, Southeastern New Mexico}

\section{Introduction}

The study of fluid inclusions in halite from the proposed Waste Isolation Pilot Plant (WIPP) site near Carlsbad, NM, has been of considerable interest owing to the presence of brine pockets encountered during preliminary drilling operations. These brine reservoirs, flowing at rates of several hundred to several thousand bpd (Register, 1981), were discovered during the drilling of ERDA-6 and WIPP-12 at depths of 2710 and $3000 \mathrm{ft}$, respectively. In both of these holes, the brines were encountered near the base of the uppermost anhydrite unit in the Castile Formation.

The source of these brine pockets is not yet clear; neither is the origin of fluids in the intracrystalline inclusions commonly present in halites throughout the halite-bearing zones. It is the object of this report to examine fluid inclusions in selected Delaware Basin halites from the perspective of a possible relationship between these inclusions and the accumulation of brine reservoirs.

The primary consequences of large brine reservoirs at or near the WIPP are the threats to containment of low-level radioactive waste posed by possible fluid movement of the brine, and resultant corrosion of waste canister material. Complementary studies (Lambert, 1983; Borns, 1983) were made to determine the extent of any past brine flow through the formations and to evaluate the potential for recurrence of this phenomenon.

Samples selected for this study came primarily from the Salado and Castile Formations. These two units, together with the Rustler Formation, constitute the upper Permian series designated as the Ochoan and overlie the Guadalupian Bell Canyon Formation. Both the Castile and the Salado Formations attain maximum thicknesses of $\sim 2000 \mathrm{ft}$ around the WIPP site. The Castile is composed primarily of interbedded halite $(\mathrm{NaCl})$ and anhydrite $\left(\mathrm{CaSO}_{4}\right)$ ranging in thickness from fine laminae $(\sim 1 \mathrm{~cm})$ to massive beds. Farther up in the stratigraphic section, the Salado consists dominantly of massive halite containing $\mathrm{mi}$ nor anhydrite; polyhalite $\left[\mathrm{K}_{2} \mathrm{MgCa}_{2}\left(\mathrm{SO}_{4}\right)_{4} \cdot 2 \mathrm{H}_{2} \mathrm{O}\right]$ appears to become more abundant with decreasing depth. A detailed description of the lithology and stratigraphy of the Delaware Basin can be found in Adams (1965). Hereafter, this paper is limited to a discussion of the lithology of the Castile and lower Salado Formations only.

Several mechanisms have been proposed (Register, 1981) to explain the origin of fluids trapped in halite inclusions in at least the portions of the Castile and lower Salado examined in this study:

1. Fluid inclusions result from the dehydration of primary gypsum as it converts to anhydrite: $\mathrm{CaSO}_{4} \cdot 2 \mathrm{H}_{2} \mathrm{O} \rightarrow \mathrm{CaSO}_{4}+2 \mathrm{H}_{2} \mathrm{O}$. This excess water then migrates locally into the adjacent halite as fluid inclusions.

2. Intergranular water in halite is mobilized by deformation and subsequently moves into the halite as fluid inclusions under the influence of such factors as lithostatic pressure, geothermal gradients, and deformation pressure.

3. Permian seawater trapped in primary anhydrite as either inter- or intragranular fluid migrates into the adjacent halite as fluid inclusions.

4. Dissolution fluids moving through the Castile and Salado Formations at postdepositional (but as yet undetermined) times migrated into and through the halite.

5. Fluid inclusions contain meteoric water that diffused intermittently throughout these parts of the Castile and Salado Formations. 
6. Fluid inclusions represent original Permian seawater trapped in situ; they formed concurrently with precipitation of halite. This mechanism may explain the formation of a large portion of the fluid inclusions examined in this study, as evidenced by the appearance of primary inclusions such as those observed in the structures known as chevron or hopper crystals. However, fluid inclusions in obviously recrystallized halite may owe their presence to one or more of the processes outlined in 1 through 5 above.

With the exception of No. 6, these proposed mechanisms for the formation and migration of fluid inclusions raise the question of whether there are, in fact, any true primary inclusions in these halites $(R$. Bodnar, 1983). Fluid inclusions that have been exposed to either fluids or host lithologies that differ from their conditions of formation are properly classified as secondary. However, this author concurs with others (Roedder and Belkin, 1979; Callender and Ingwell, 1978), who believe that fluids in hopper crystals reflect primary formation resulting from entrapment of water on the growing faces of halite crystals.

To summarize briefly at this point, the following processes may result in only very localized fluid movement: (1) the formation of fluid inclusions by gypsum dewatering, (2) entrapment of Permian seawater in anhydrite, and (3) mobilization of intergranular water. In particular, the hypotheses involving dewatering of gypsum and seawater entrapment in anhydrite are strongly supported by the apparent concentration of fluid inclusions in halite immediately adjacent to anhydrite, as observed in the samples examined in this study. Basin-wide processes such as the movement of dissolution fluids through these formations, or intermittent large-scale diffusion of meteoric water also suggest secondary inclusions; but they may also indicate fluid movement on a regional scale as proposed by Lambert (1983), Dean and Anderson (1978), Anderson et al (1978), and others.

\section{Methods}

This reconnaissance study was conceived for the specific purpose of determining what information could be gained from analyzing fluid inclusions in halite from the Castile and lower Salado Formations. Initially, it was hoped that measuring freezing-point depressions might define significant compositional differences between fluid-inclusion populations and hence possibly indicate different sources for the water they contain. The study of fluid inclusions in this part of the stratigraphic section is relevant to the specific question of the origin(s) of the brine reservoirs, as well as to the hydrology and migration of fluids in general throughout the Delaware Basin. The measurement of freezing-point depressions does not in itself confirm or refute any particular hypothesis relating to the origin and history of the formation waters. Data obtained from freezing-point analyses were nonetheless useful in suggesting alternative approaches, specifically other analytical methods for acquiring data that could be used to eliminate some of these hypotheses.

Halite samples were selected from core of ERDA-6, ERDA-9, ERDA-10, WIPP-12, and DOE-1. Samples were taken immediately adjacent to halite-anhydrite contacts, in the middle of thick halite sequences, and in deformed as well as undeformed halite.

According to previous work by Roedder (1962), Roedder and Belkin (1979), and others, halite samples from the Delaware Basin indicate temperatures of deposition between $25^{\circ} \mathrm{C}$ and $45^{\circ} \mathrm{C}$, essentially nearsurface conditions, as expected in a geologic setting such as an evaporite basin in the Permian of western Texas and southeastern New Mexico. Heating measurements are usually made only on high-temperature minerals associated with ore deposits-typically, quartz, calcite, and fluorite. Fluid inclusions in oretype assemblages frequently contain vapor bubbles resulting from fluid entrapment at very high temperatures. Therefore, heating-stage analyses (i.e., heating these inclusions until the point of vapor-liquid homogenization is observed) are of great value for temperature determination of ore-forming fluids. However, it seems obvious that the presence of vapor bubbles in fluid inclusions in evaporitic halite, probably deposited at temperatures of $25^{\circ} \mathrm{C}$ to $45^{\circ} \mathrm{C}$, does not imply deposition from a high-temperature solution.

Since Roedder's values for homogenization temperatures are consistent with environmental conditions for evaporite deposition, it was decided to forego high-temperature measurements on fluid inclusions from these samples and to concentrate primarily on analyses of freezing-point depressions, at least for the present. Heating measurements may prove to be important in subsequent studies of diagenetic or deformational effects. A Chaixmeca heating-freezing stage, maintained by the Department of Geology at the University of Texas at El Paso, was used to make these measurements. Initially, samples were prepared by cutting and doubly polishing thick (3- to $4-\mathrm{mm}$ ) sections of halite core mounted on glass slides. Because it was later necessary to break up these sections before mounting small fragments for use in the freezing apparatus, it was deemed more efficient simply to cleave individual halite crystals through judicious use of a rock hammer and a single-edged razor blade. 
For analyses of freezing-point depressions, these sample slices were mounted directly on the cooling stage, which was attached to a Zeiss microscope. Thermocouples attached to the stage controlled the freezing rate. Freezing was achieved by circulating dry $\mathrm{N}_{2}$ through a liquid- $\mathrm{N}_{2}$-filled Dewar and then through the cooling stage. Because of kinetic problems in the freezing of brine solutions, it was usually necessary to drop the temperature to $-70^{\circ} \mathrm{C}$ or lower to induce freezing in these inclusions. However, the temperatures at which inclusions finally froze were not at all related to "freezing temperatures," as the term is used in fluid-inclusion studies.

After all the liquid in an inclusion had turned to crystalline solids, it was allowed to warm up; the point at which liquid water is first visible is termed the "first melting point" (Roedder, 1962). The temperature at which the last crystal in a frozen inclusion turns to liquid is the freezing temperature or freezing point. It is believed that the freezing data in this report are accurate, reproducible, and have a standard error of $\pm 0.1^{\circ} \mathrm{C}$. All freezing-point determinations were made according to the method described by Roedder (1962). Results of these analyses are shown in Table 1.

One problem encountered was the condensation of atmospheric moisture on the sample surface during cooling, owing to the hygroscopic character of $\mathrm{NaCl}$. This condensation almost invariably obscured the temperature of first melting, often making it difficult to observe freezing points. The problem was alleviated somewhat by mounting the sample slices individually on Vaseline-coated glass cover slips and surrounding these slices with crystals of $\mathrm{CaCl}_{2}$. It would appear to be advantageous to design a sample chamber for any conventional cooling stage that could either be evacuated before cooling or could contain a desiccant to further minimize condensation.

Samples were also examined petrographically for general shape, size, and distribution of inclusions. The photographs in Figure 1 indicate that, most commonly, the inclusions maintain a cubic symmetry. However, inclusions that are aligned along what appear to be shear planes or annealed fractures are often rounded, stretched, and deformed (Figure 2). This feature is especially prominent in samples with macroscopic fabric or alignment of halite crystals (e.g., what is usually referred to as "brickwork" texture) and is presumed to result from mechanical deformation of the halite. Several samples that had been deformed under controlled conditions in a set of experiments conducted by W. Wawersik (Division 1542) were also examined petrographically. Note the visible changes in fluid-inclusion geometry as a function of applied load (Figures 3 and 4). Investigations of the mechanics of this phenomenon are currently being planned.

Table 1. Freezing-Point Depressions ${ }^{a}$

\begin{tabular}{|c|c|c|c|c|}
\hline Core & $\begin{array}{c}\text { Sample } \\
\text { No. }\end{array}$ & $\begin{array}{c}1^{\text {st }} \text { Melt } \\
\text { Point } \\
\left({ }^{\circ} \mathrm{C}\right)^{\mathrm{c}}\end{array}$ & $\begin{array}{c}\text { Freezing } \\
\text { Temp } \\
\left({ }^{\circ} \mathrm{C}\right)^{\mathrm{c}}\end{array}$ & Comments \\
\hline \multirow[t]{3}{*}{ ERDA-9 } & $9-2828.4$ & $\begin{array}{c}-36.8 \\
-30 \\
-35 \\
-30 \\
-34 \\
-38 \text { to }-33\end{array}$ & $\left.\begin{array}{c}-2.1 \\
-2.7 \\
--10 \\
-10 \\
-25 \\
-28.3 \\
-28 \\
-24 \\
-29.8 \\
-29.0 \\
-3.1\end{array}\right\}$ & $\begin{array}{l}\text { Adjacent to anhydrite } \\
\text { In hopper crystal close to anhydrite } \\
\text { Same inclusions } \\
\text { Clear crystal } \sim 1 \mathrm{~cm} \text { below anhydrite } \\
\text { Clear crystal } \sim 1 \mathrm{~cm} \text { below anhydrite }\end{array}$ \\
\hline & $9-2828.4$ & & -4.7 & \\
\hline & $9-2819.0$ & -35 & $\left.\begin{array}{l}-29 \\
-25.2 \\
-25.0 \\
-2.5 \\
-24.6 \\
-\quad 1.7\end{array}\right\}$ & $\sim 1 \mathrm{~cm}$ above anhydrite lamellae \\
\hline
\end{tabular}


Table 1. (Continued)

\begin{tabular}{|c|c|c|c|c|}
\hline Core & $\begin{array}{c}\text { Sample } \\
\text { No. }^{\mathrm{b}}\end{array}$ & $\begin{array}{c}1^{\text {st }} \text { Melt } \\
\text { Point } \\
\left({ }^{\circ} \mathrm{C}\right)^{\mathrm{c}}\end{array}$ & $\begin{array}{c}\text { Freezing } \\
\text { Temp } \\
\left({ }^{\circ} \mathrm{C}\right)^{\mathrm{c}}\end{array}$ & Comments \\
\hline & & -34.9 & $\left.\begin{array}{r}-26.2 \\
-1.7 \\
-26.5 \\
-22.1 \\
-1.8 \\
-28.6 \\
-25.0 \\
-12.6 \\
-1.7\end{array}\right\}$ & $\begin{array}{l}\text { Hopper crystal } \\
\text { Slightly elongate }\end{array}$ \\
\hline & $9-2822.0$ & 25 & -0.3 & $\sim 2 \mathrm{~cm}$ above anhydrite \\
\hline \multirow[t]{2}{*}{ ERDA-6 } & $6-2552.0$ & $\begin{array}{l}-30 \\
-27 \\
-25\end{array}$ & $\begin{array}{r}0.0 \\
-1.1 \\
-0.3 \\
0.0\end{array}$ & \\
\hline & $6-2548.5$ & -30 & $\begin{array}{r}-0.7 \\
0.0\end{array}$ & \\
\hline \multirow[t]{3}{*}{ WIPP-10 } & $10-2339.4$ & $\begin{array}{l}-35.8 \\
-35\end{array}$ & $\begin{array}{r}-4.2 \\
-2.6 \\
-27.8 \\
-2.3\end{array}$ & $\sim 1 \mathrm{~cm}$ from anhydrite band \\
\hline & $10-2324.2$ & $\begin{array}{l}-35 \\
\\
-45 \\
-27.4\end{array}$ & $\left.\begin{array}{c}-26 \\
-24.6 \\
-2.4 \\
-3.5 \\
-3.8\end{array}\right\}$ & $\begin{array}{l}\text { Clear crystal } \sim 2 \mathrm{~cm} \text { above anhydrite } \\
\text { In hopper crystal } \\
\text { In clear halite close to anhydrite }\end{array}$ \\
\hline & $10-2328.5$ & $\begin{array}{l}-31.5 \\
-34.8\end{array}$ & $\begin{array}{l}-4.6 \\
-3.8 \\
-2.9 \\
-4.0 \\
-3.8 \\
-1.5\end{array}$ & \\
\hline \multirow[t]{6}{*}{ WIPP-12 } & $12-2483.3$ & -32.7 & $\begin{array}{l}-2.2 \\
-1.9 \\
-1.4 \\
-0.4\end{array}$ & \\
\hline & $12-3060.4$ & $\begin{array}{l}-44 \text { to }-39 \\
-58 \\
-52\end{array}$ & $\begin{array}{l}-10.3 \\
<-7.1 \\
<-6.1\end{array}$ & \\
\hline & $12-2467.4$ & & -23.1 & \\
\hline & $12-3055.8$ & & -17.6 & \\
\hline & $12-2741.5$ & -37 & -22.1 & \\
\hline & $12-3275.4$ & & -16.1 & \\
\hline
\end{tabular}




\section{Table 1. (Concluded)}

\begin{tabular}{|c|c|c|c|c|}
\hline Core & $\begin{array}{c}\text { Sample } \\
\text { No. }\end{array}$ & $\begin{array}{c}1^{\text {st }} \text { Melt } \\
\text { Point } \\
\left({ }^{\circ} \mathrm{C}\right)^{c}\end{array}$ & $\begin{array}{c}\text { Freezing } \\
\text { Temp } \\
\left({ }^{\circ} \mathrm{C}\right)^{\mathrm{c}}\end{array}$ & Comments \\
\hline & $12-3077.5$ & -35.3 & $\left.\begin{array}{l}-0.4 \\
-0.6 \\
-1.2 \\
-1.6 \\
-0.2\end{array}\right\}$ & In one large crystal-may be hopper crystal \\
\hline & $12-3386.0$ & & $\left.\begin{array}{l}-10.3 \text { to }-7.9 \\
-13.1 \text { to }-4.2\end{array}\right\}$ & $\begin{array}{l}\text { Inclusions deformed; } \\
\text { disseminated anhydrite }\end{array}$ \\
\hline & $12-3174.5$ & -30.8 & $\begin{array}{l}-0.8 \\
-0.2\end{array}$ & \\
\hline & $12-2050.2$ & -27 to -30 & $\begin{array}{l}-2.7 \\
-2.9 \\
-2.6 \\
-2.5\end{array}$ & \\
\hline \multirow[t]{7}{*}{ DOE-1 } & 3374.1 & $\begin{array}{l}-22.1 \\
-30 \\
-22\end{array}$ & $\begin{array}{l}+3.9 \\
-0.3 \\
+1.6\end{array}$ & \\
\hline & 2297 & -30 & $\begin{array}{l}-2.9 \\
-1.5\end{array}$ & \\
\hline & 3708 & -22.4 & $\begin{array}{r}-10.0 \\
-9.2\end{array}$ & \\
\hline & 3709 & $\begin{array}{l}-21.4 \\
-21.7\end{array}$ & $\begin{array}{l}+0.0 \\
-0.2\end{array}$ & \\
\hline & 3709 & -22.9 & +0.1 & \\
\hline & 3380.7 & $\begin{array}{l}-30 \\
-26\end{array}$ & $\begin{array}{l}-1.9 \\
-0.9 \\
-0.2\end{array}$ & \\
\hline & 4031 & & $\begin{array}{l}-31 \\
-44.1 \\
-29.0\end{array}$ & Very linear fabric; crystals small \\
\hline
\end{tabular}

${ }^{a}$ Each measurement is for a different inclusion unless otherwise noted.

bample numbers refer to depth in core.

'For further discussion of first melting points and freezing temperatures, see Roedder (1962). 


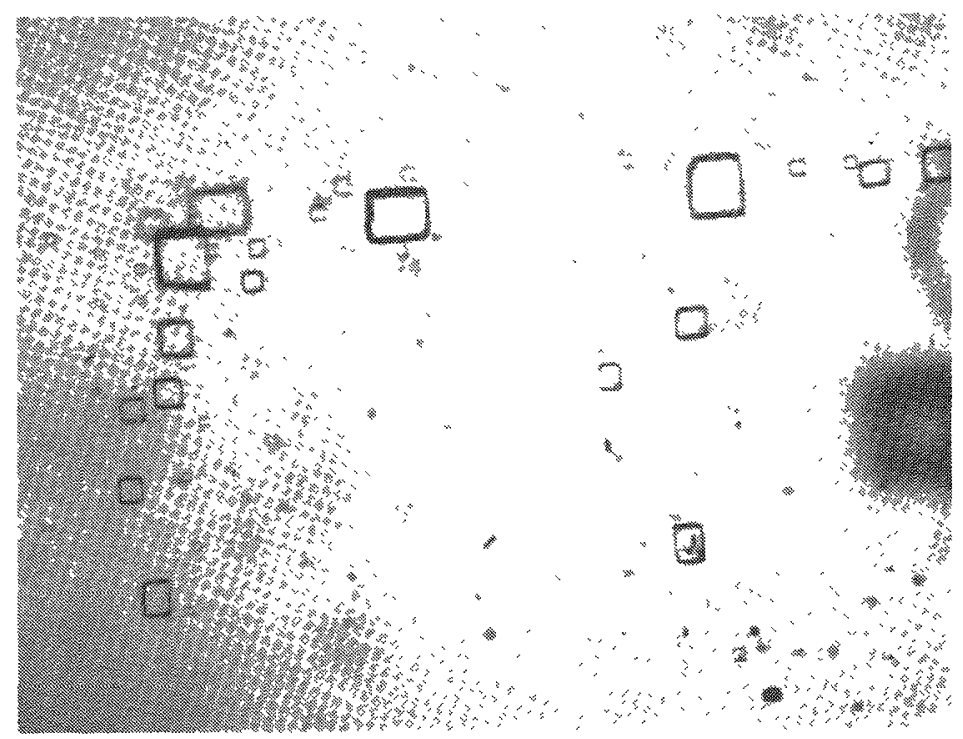

(a) Sample 9-2671 (undeformed): Inclusions are euhedral cubes, aligned along right-angle growth planes in the classic "hopper crystal" configuration.

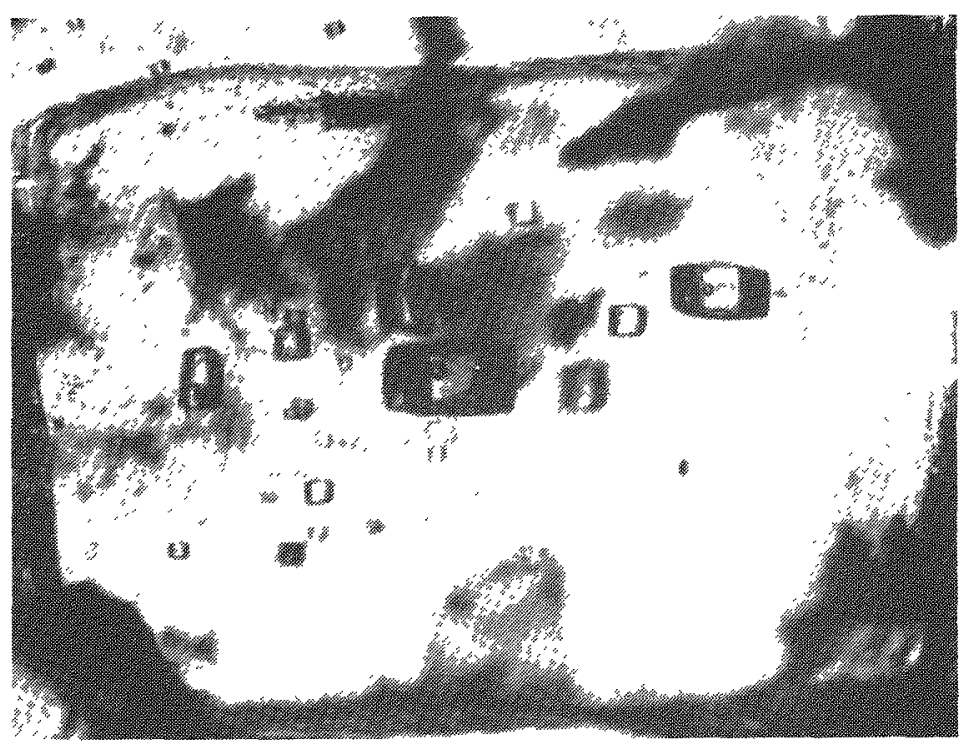

(b) Sample 9-2625.5 (undeformed): Inclusions in remanent hopper crystal structure, near grain boundary (near top of photograph). Inclusions containing gas bubbles may be locally common, perhaps resulting from leakage during recrystallization.

Figure 1. Photographs of Sample Inclusions 


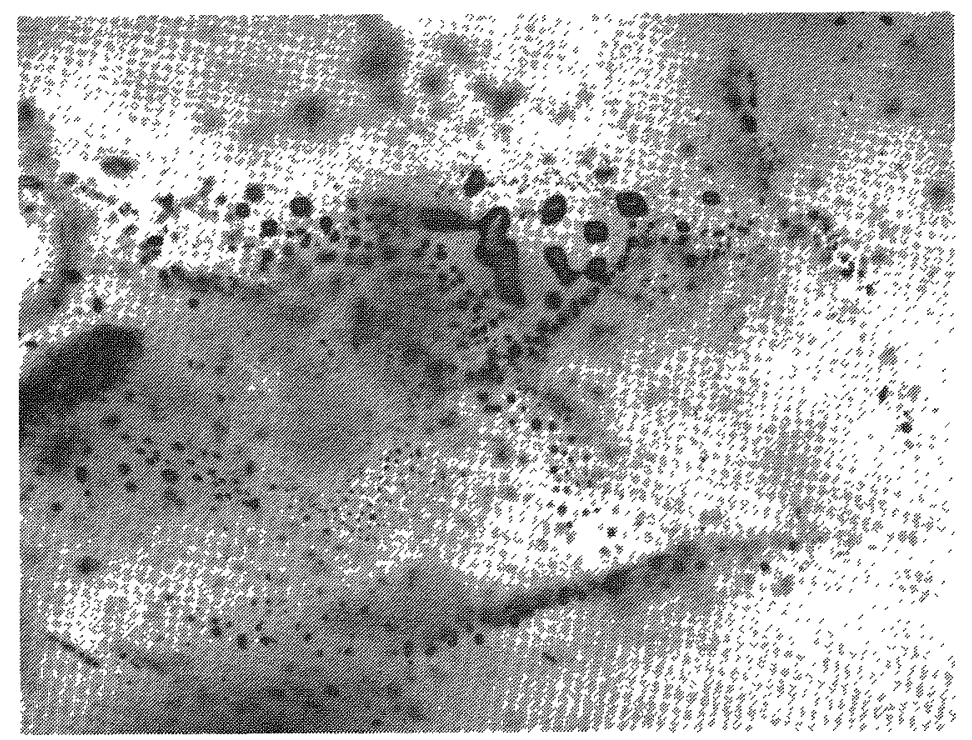

Figure 2. Sample 9-2677: $<1 \%$ Mechanical Deformation. (Inclusions on grain boundaries showing typical "smeared-out" texture of mechanically deformed inclusions; from Carter and Hansen, 1983.) 


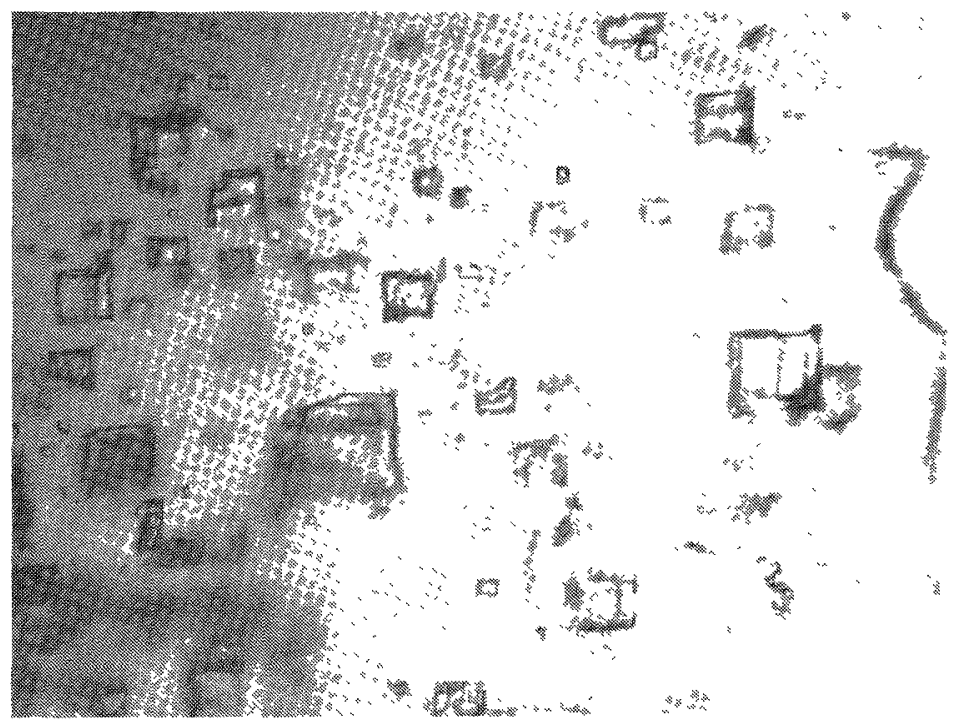

(a) Magnification $\mathrm{X} 63$

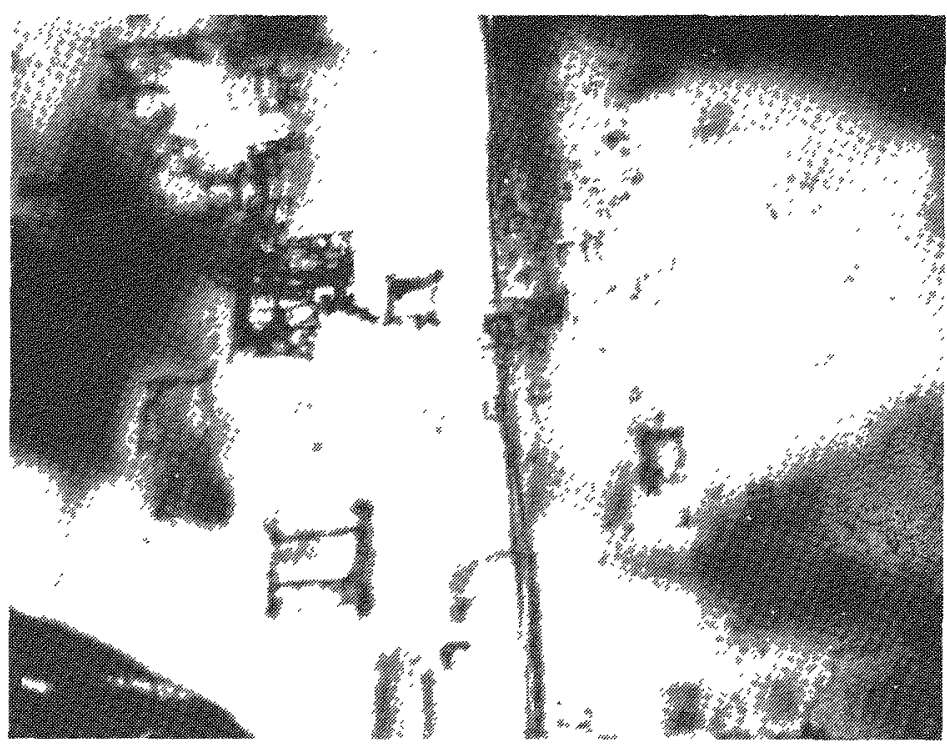

(b) Magnification X160

Figure 3. Sample 2625: This Sample, a Product of the Experimental Work of W. Wawersik, Has Undergone 7\% Deformation. (The inclusions seen here exhibit a strikingly different texture from the smooth-walled, euhedral, undeformed inclusions seen in Figure 1. Moreover, the morphology of these inclusions is distinctly different from the "smeared-out" shape of those seen in Figure 2. 

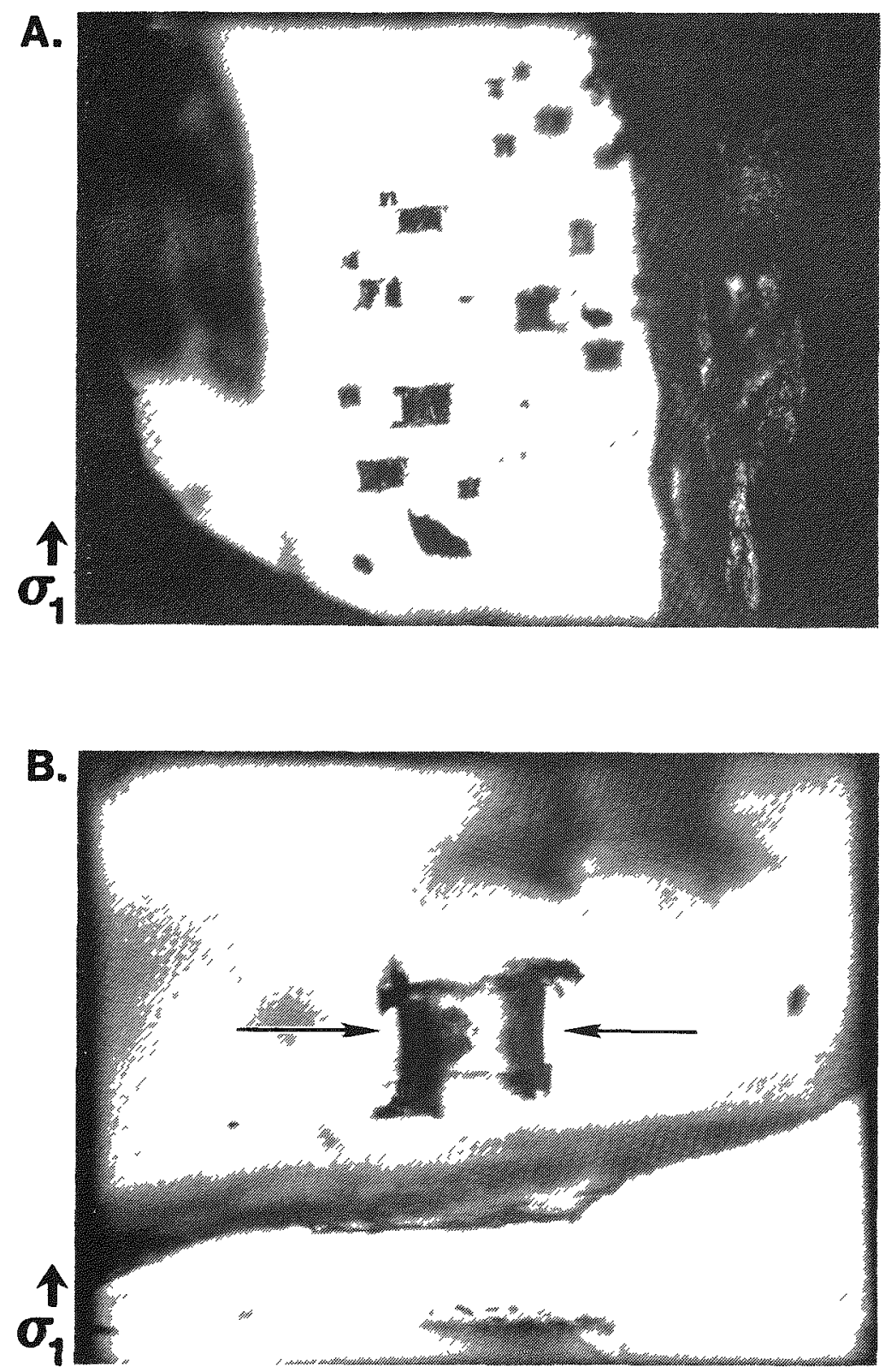

Figure 4. Sample 2625: As Seen in Figure 3, 7\% Deformation. (Note particularly the deformation at the corners and edges of the inclusions. This appearance is attributed to the processes of $\mathrm{NaCl}$ dissolution and reprecipitation in a stress gradient, an as-yet poorly understood phenomenon. High-magnification photomicrographs of these and other fluid inclusions in mechanically deformed samples show trains or shadows of extremely small inclusions along the former walls of the inclusions shown here (the arrows in Figure 4(b), suggesting that these sides are the loci of $\mathrm{NaCl}$ precipitation during inclusion deformation.) 
By far the greatest density (i.e., abundance) of fluid inclusions occurs in hopper crystals. This structure is assumed to be a growth feature and therefore indicative of essentially undeformed halite, although fragments of crystals containing evidence of hopper growth are occasionally seen in otherwise deformed halite. Hopper crystals contain the greatest abundance of fluid inclusions $\left(\geq 10^{5} / \mathrm{cm}^{3}\right)$, aligned in bands parallel to the growing crystal faces (Figure 5). The density of fluid inclusions along these faces is so great that these bands are often milky in appearance as a result of the parallel alignment of thousands of tiny inclusions. The overwhelming abundance of fluid inclusions in hopper structures, as seen in samples examined in this study, appears to be located almost immediately adjacent (within 1 to $2 \mathrm{~cm}$ ) to anhydrite veins or lamellae. In contrast, in large, clear halite crystals not associated with anhydrite, fluid inclusions are much larger ( 0.1 to $1 \mathrm{~mm}$ on a cube edge) and are several orders of magnitude less abundant in number.

Fluid-inclusion volume (as volume percent of the host halite) was calculated from measurements taken from polished thick sections. Approximately 300 fluid inclusions were measured by using four microscope objectives (2.5X, $6.3 \mathrm{X}, 16 \mathrm{X}$, and $25 \mathrm{X})$. Volume calculations based on the calibration factors for these objectives with the stage micrometer yielded a fluidinclusion volume of $\sim 1 \%$ of the whole-rock volume. This result is in good agreement with those obtained by Roedder and Belkin (1979) from WIPP salt and by Roedder and Bassett (1981) from Palo Duro Basin (TX) salt.

Because this investigation was formulated originally as a pilot study to evaluate the usefulness of fluid inclusions as indicators of brine origin and migration, it was decided at this point to tabulate the results obtained thus far. Freezing-point temperatures did not appear to exhibit any consistent trends as a function of stratigraphic position or associated lithology, as indicated in the "Discussion" section that follows. The schematic plots shown in Figures 6 through 9 support the hypothesis that at least some of the fluid inclusions analyzed here are generically related to the adjacent anhydrites. In general, freezing points of fluid inclusions in halites that were close to anhydrites are significantly lower than freezing points of inclusions taken from halite that is much farther from halite-anhydrite contacts. This conclusion is summarized by the data shown in Figure 10 for WIPP-12.

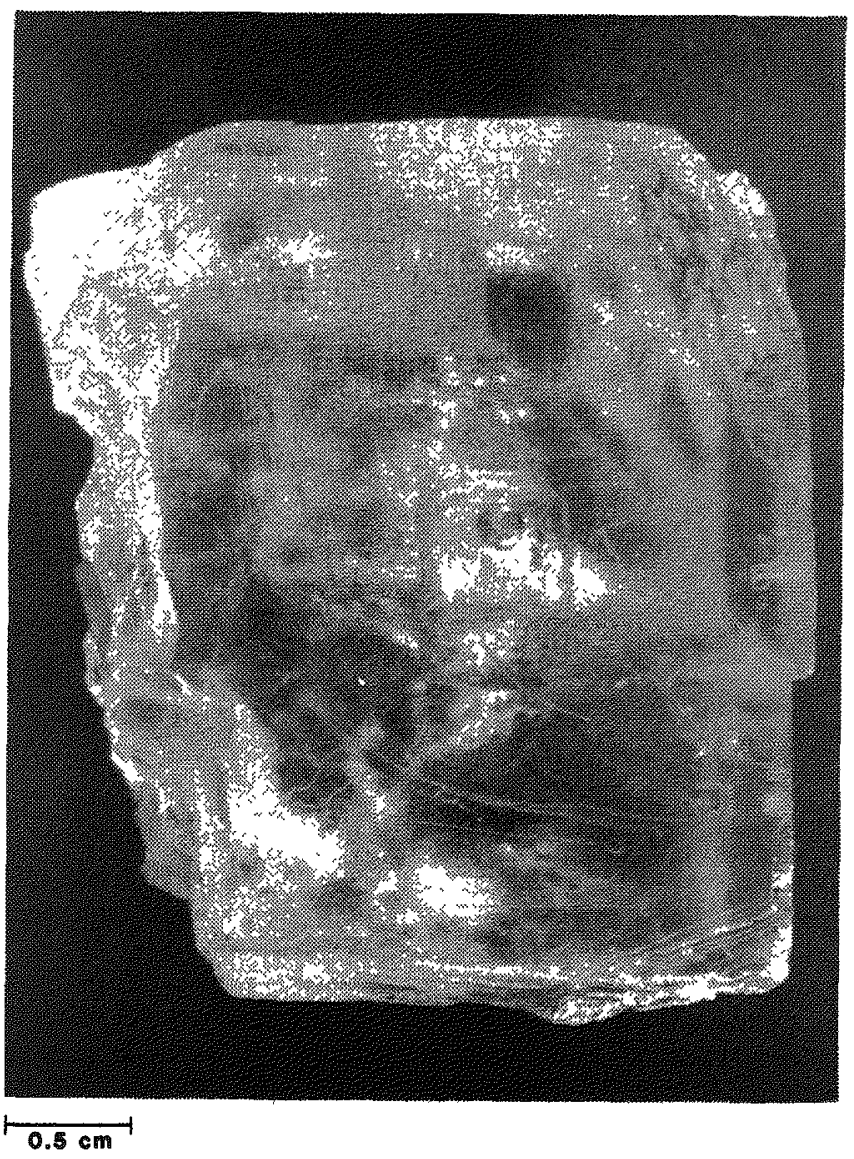

Figure 5. Sample of Lower Salado Formation Salt From the Level of the Facility Horizon at $2150 \mathrm{ft}$. (This example contains extremely large fluid inclusions in clear, recrystallized salt, such as that seen in the center of the photograph (with bubble). In the unrecrystallized upper left corner, the milky bands composed of thousands of microscopic fluid inclusions define a primary "hopper" crystal. Scale bar = $0.5 \mathrm{~cm}$.) 


\section{ERDA-6}

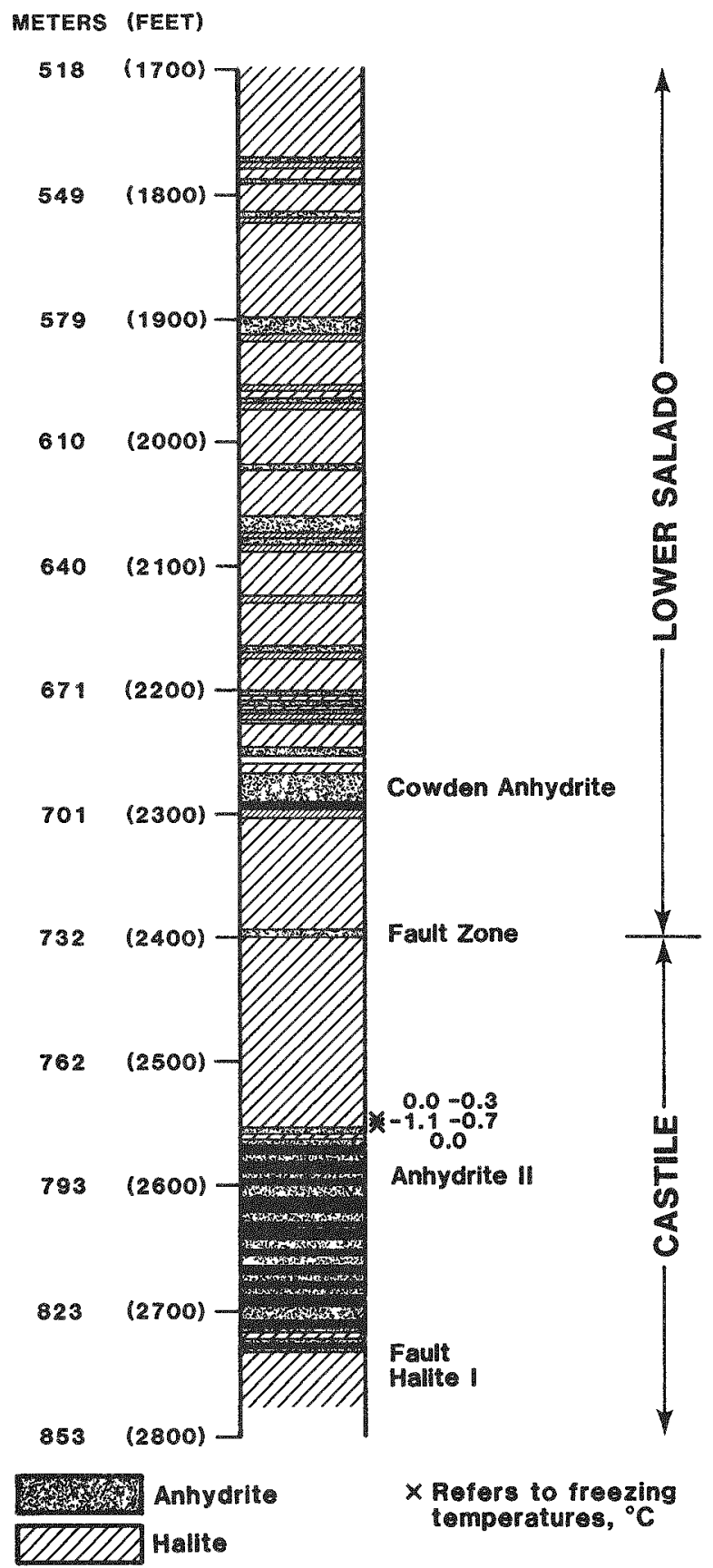

Figure 6. ERDA-6 Lithology (from Sandia Report SAND79-0267) Showing Distribution of Halite and Anhydrite. (Positions of fluid-inclusion samples and freezing temperatures, in ${ }^{\circ} \mathrm{C}$, are also shown.) 


\section{WIPP-12}

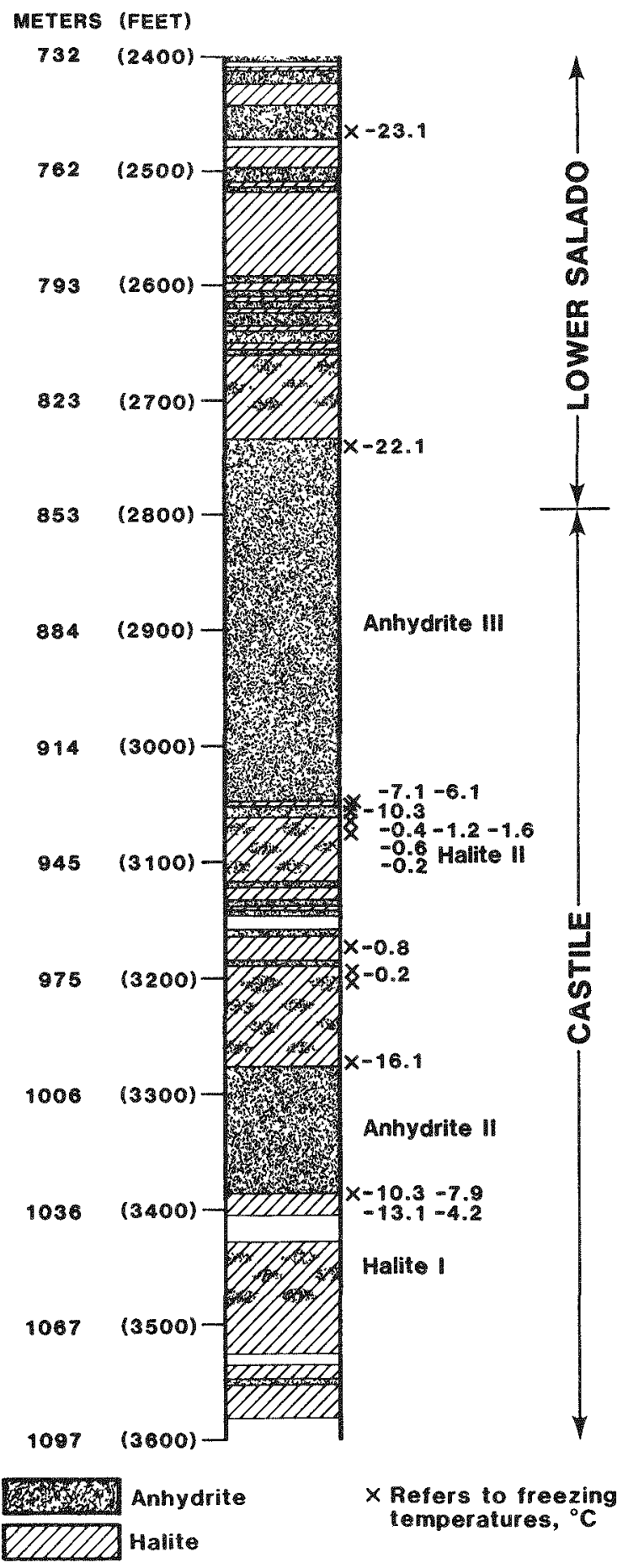

Figure 7. WIPP-12 Lithology (from Sandia Report SAND82-2336) Showing Distribution of Halite and Anhydrite. (Positions of fluid-inclusion samples and freezing temperatures, in ${ }^{\circ} \mathrm{C}$, are also shown.) 


\section{ERDA-9}

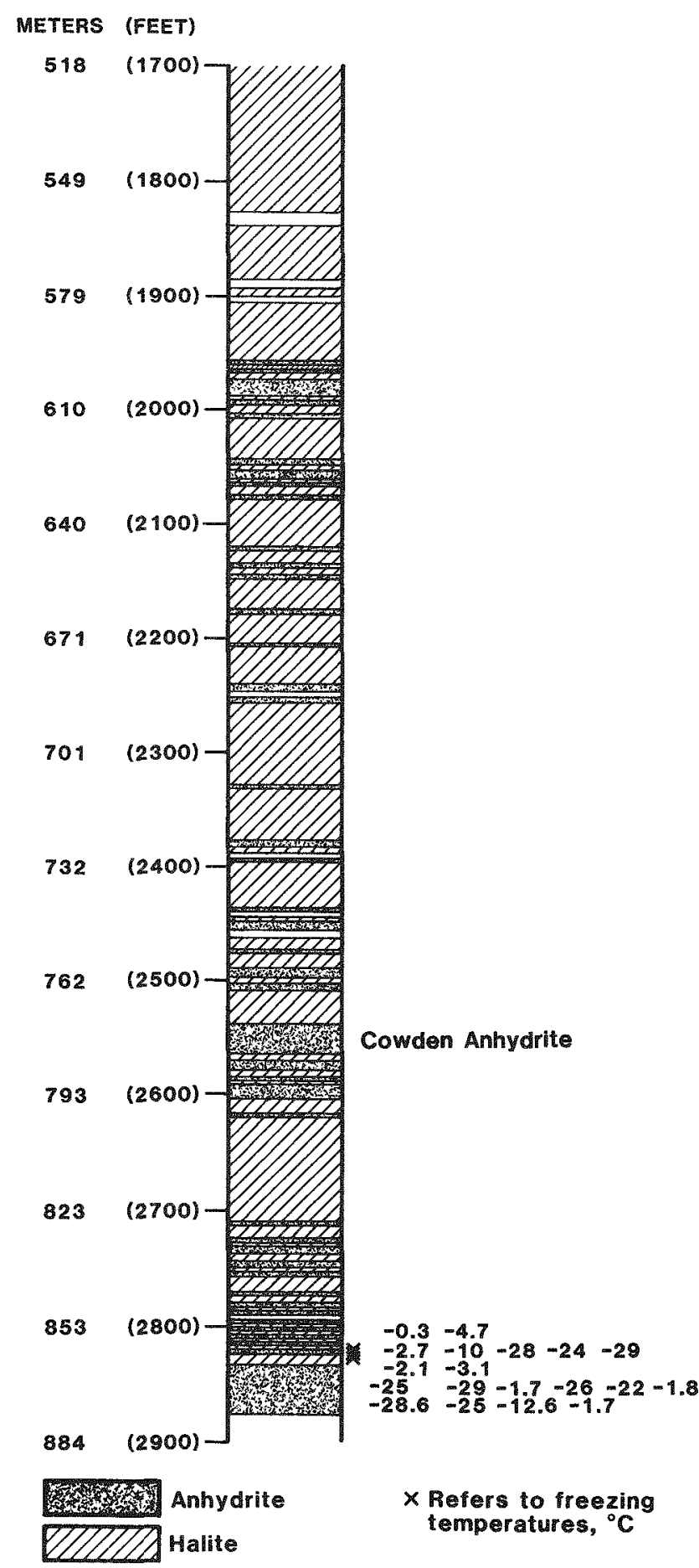

Figure 8. ERDA-9 Lithology (from Sandia Report SAND79-0270) Showing Distribution of Halite and Anhydrite. (Positions of fluid-inclusion samples and freezing temperatures, in ${ }^{\circ} \mathrm{C}$, are also shown.) 


\section{DOE-1}

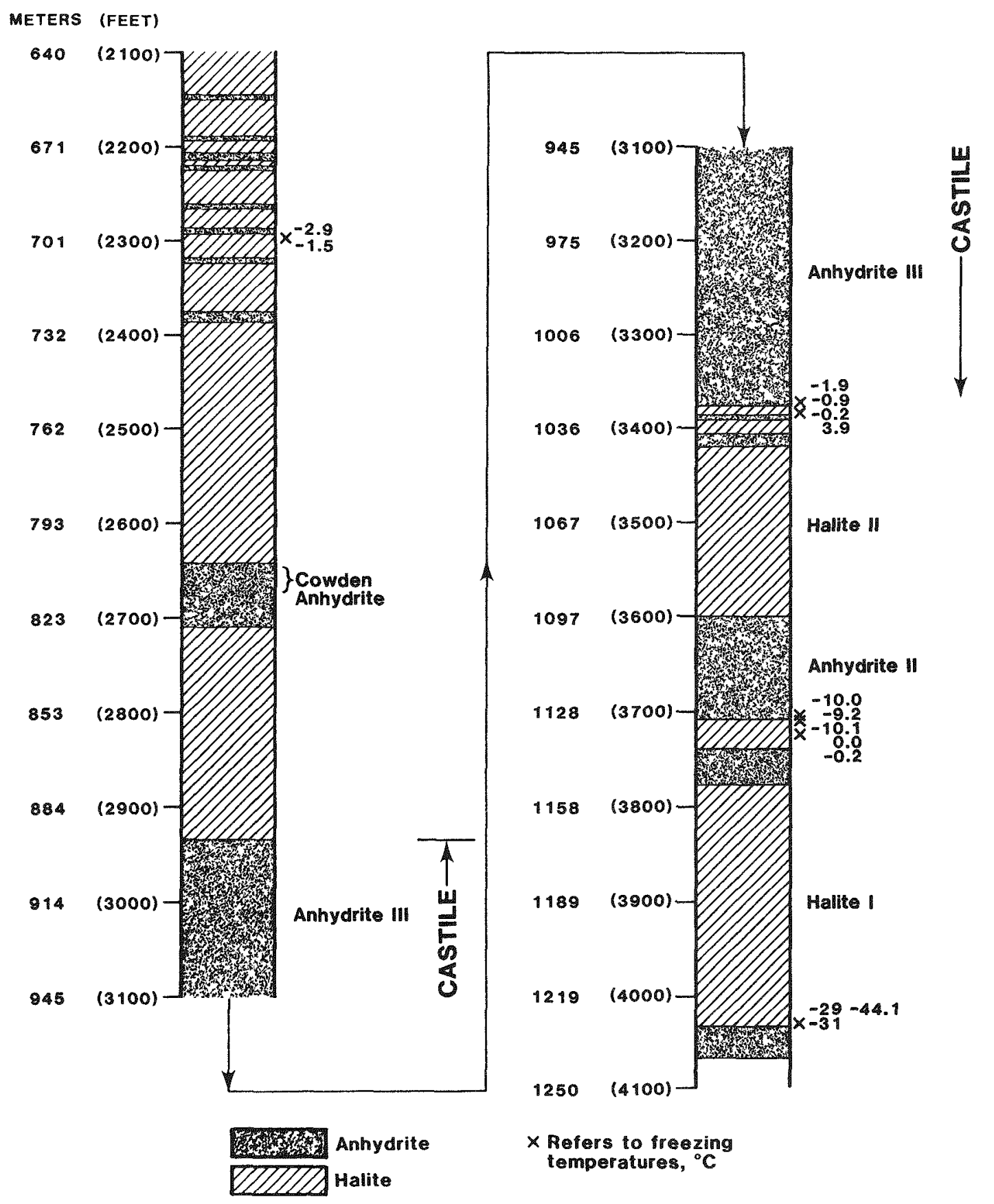

Figure 9. DOE-1 Lithology (Freeland, 1982) Showing Distribution of Halite and Anhydrite. (Positions of fluid-inclusion samples and freezing temperatures, in ${ }^{\circ} \mathrm{C}$, are also shown.) 


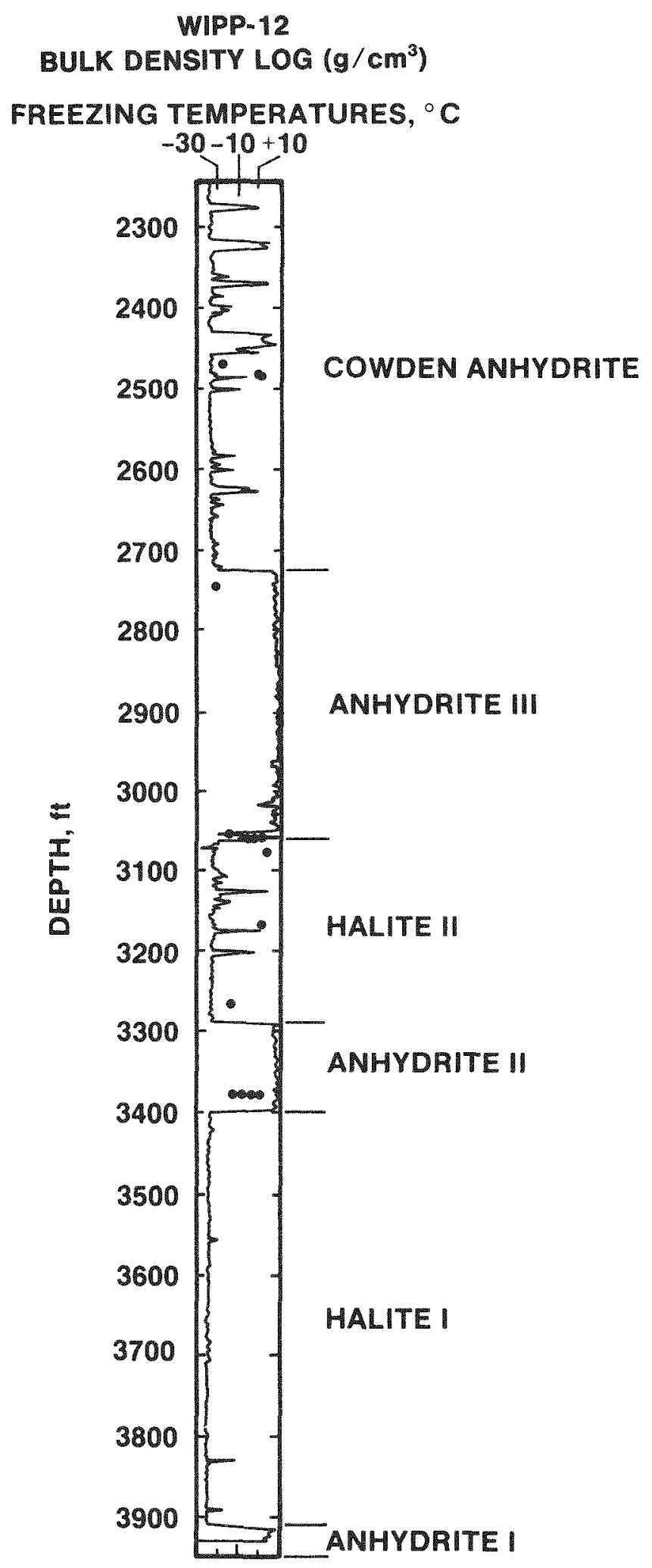

Figure 10. Freezing Temperatures vs Lithology in WIPP-12. (Bulk density log of a portion of WIPP-12 shows freezing temperatures of fluid inclusions and their relative proximity to anhydrite-halite contacts.) 
These freezing measurements seem to suggest that one or more of the previously discussed mechanisms implicating gypsum and/or anhydrite in the formation of fluid inclusions may be responsible for this distribution of freezing temperatures. This conclusion is reinforced by additional compositional data on fluid inclusions from the WIPP facility horizon. A comprehensive discussion of these data and their chemical evolution are soon to be forthcoming (Stein and Krumhansl, in progress).

It would be of great interest to perform identical analyses on fluid inclusions from the associated anhydrites. The expectation is that the Ca content of fluids in anhydrite and adjacent halite would be similar if in fact the fluid compositions are related. However, the freezing-point temperatures from the WIPP-12 samples were plotted against the neutron density log from that hole because the freezing data from WIPP-12 were abundant and the logs were available (Figure 10). The distribution of the freezing data suggests that extremely low freezing temperatures tended to occur in samples taken in halite immediately adjacent to very thick anhydrite layers (e.g., at the contacts between Halite III and Anhydrite III, Anhydrite III and Halite II, Halite II and Anhydrite II, etc). Because it is well established that significant quantities of calcium ion depress freezing temperatures much below the eutectic for the $\mathrm{NaCl}-\mathrm{H}_{2} \mathrm{O}$ system (see, for example, Weast, 1974), the WIPP-12 data suggest the possibility of a connection between very low freezing points and excess $\mathrm{Ca}^{2+}$ from adjacent anhydrites.

In general, it is unclear what value should be attached to freezing-point measurements of fluid inclusions in halites. Owing to the potential complexity of the solution compositions involved, the kinetics of the phase transformations, problems of metastability in vapor, liquid, and solid phases, and mechanical problems such as cracking or leaking of inclusions on freezing, it seems apparent that such analyses must not be relied on exclusively as independent proof of any single theory's explaining brine origin and migration. Rather, these data may be useful in setting limits on the compositions of multicomponent solutions. In this context, these data are here interpreted as suggesting a possible correlation of fluid composition with adjacent lithology.

Further, the inverse relationship between $\mathrm{Ca}^{2+}$ and $\mathrm{SO}_{4}^{2-}$ concentrations in equilibrium with gypsum or anhydrite inspired the thought that low freezing temperatures (and therefore possibly high $\mathrm{Ca}^{2+}$ content) might also be correlated with low $\mathrm{SO}_{4}^{2-}$ values, according to the following:
$\mathrm{CaSO}_{4}=\mathrm{Ca}^{2+}+\mathrm{SO}_{4}^{2-}$

hence

$$
\mathrm{k}_{\mathrm{sp}}=\left[\mathrm{Ca}^{2+}\right]\left[\mathrm{SO}_{4}^{2-}\right] .
$$

To this end, a suite of samples was selected from WIPP-12 and DOE-1 for examination of dissolved $\mathrm{SO}_{4}^{2-}$ in fluid inclusions through the use of laser Raman spectroscopy.

The laser Raman technique uses an argon laser beam focused through an optical microscope and centered on the interior of a fluid inclusion. This technique, as applied to fluid inclusions, is described in detail by Tallant et al (1983). Similar applications are discussed in papers by Dubessy et al (1983) and Rosasco and Roedder (1979). Standards for this procedure consisted of various solutions of sulfate (as sodium sulfate) in a saturated $\mathrm{NaCl}$ brine. Sulfate concentrations, in ppm, were determined by the ratio of the $v_{1}$ sulfate band $\left(980 \mathrm{~cm}^{-1}\right)$ to the $v_{1}$ water band ( 3400 to $3500 \mathrm{~cm}^{-1}$ ). Results of the laser Raman analyses are presented in Table 2; the spectra of all samples run are included as Appendix A.

The dissolved sulfate values as determined by laser Raman spectroscopy are shown in Figure 11, plotted against depth in the formation. Figure 12 shows the mineralogy of a portion of the stratigraphic section as described in the lithologic logs from WIPP-12. Of extreme interest is the correlation between the apparent linear decrease in sulfate values and the presence of polyhalite, both occurring in the interval from $\sim 1000$ to $2300 \mathrm{ft}$. The possible implications of this result are discussed in the next section.

Below a depth of $\sim 2700 \mathrm{ft}$, laser Raman results showed a well-defined bimodal distribution. These values were all obtained from primary fluid inclusions selected from halite samples in close proximity (on the order of inches) to anhydrite. At present, no clear-cut explanation exists for two distinct populations, although this result is also consistent with the analyses reported by Dubessy et al (1983).

Current research to further explain the geochemistry of fluid inclusions in these halites involves extracting brine from individual inclusions. It was fortuitous that excavation for the WIPP facility intersected a horizon within the Salado, at a depth of $\sim 2150 \mathrm{ft}$, that contained unusually large inclusions. Some of these are as much as $5 \mathrm{~mm}$ on a side (Figure 5). With extreme precision and a small (No.65) drill bit, it was possible to drill a hole directly into several of these inclusions and remove the liquids by means of a 
preweighed 25-gauge hypodermic syringe. Weights of the inclusion fluids were recorded, the fluids were injected into preweighed polyethylene vials, water was added, and a dilution factor was then calculated.

These samples were analyzed by argon-plasma emission spectroscopy for $\mathrm{K}^{+}, \mathrm{Na}^{+}, \mathrm{Ca}^{2+}$, and $\mathrm{Mg}^{2+}$ by J. L. Krumhansl (Div 1543). For the purpose of calculating a cation-anion balance, $\mathrm{Cl}^{-}$was analyzed by titration, and $\mathrm{SO}_{4}^{2-}$ values were taken to be those obtained from inclusions in this horizon by laser Raman spectroscopy. From these numbers, the ratio of
$\mathrm{M}^{+}: \mathrm{M}^{-}$is 1.00 , giving credibility to the belief that these analyses are accurate to within the detection limits of the analytical procedures used.

This work is currently in progress; therefore, results obtained so far will not be reported here. Briefly, we feel that we have established a data base that is sufficient for defining two distinct fluid inclusion populations from this horizon, based on groupings of the cation compositions. From these data we have formulated an explanation for compositional variation in these brines that is the result of clay alteration and evaporite mineral diagenesis.

\section{Table 2. Laser Raman Spectroscopy Analyses for Dissolved Sulfate in Fluid Inclusions}

\begin{tabular}{|c|c|c|c|c|}
\hline Sample & $\begin{array}{l}\text { Sample Depth } \\
\text { (ft) }\end{array}$ & $\begin{array}{c}\text { Band Ratio } \\
\left(\mathrm{SO}_{4} / \mathrm{OH}\right)\end{array}$ & $\begin{array}{c}\mathrm{SO}_{4} \\
(\mathrm{ppm})\end{array}$ & $\begin{array}{l}\text { Est. Error } \\
\left(\mathrm{ppm} \mathrm{SO}_{4}\right)\end{array}$ \\
\hline WIPP-12 & 1125 & $\leq 0.004$ & $\leq 100^{\mathrm{b}}$ & $\leq 500$ \\
\hline WIPP-12 & 1125 & $\leq 0.007$ & $\leq 400^{b}$ & $\leq 500$ \\
\hline WIPP-12 & 1692 & 0.085 & $7900^{c}$ & \pm 300 \\
\hline WIPP-12 & 1692 & 0.086 & $8000^{c}$ & \pm 300 \\
\hline WIPP-12 & 1692 & 0.082 & $7600^{c}$ & \pm 300 \\
\hline \multicolumn{5}{|l|}{ Facility } \\
\hline Horizon & 2150 & 0.140 & 13200 & \pm 2600 \\
\hline DOE-1 & 2297 & 0.182 & 17300 & \pm 900 \\
\hline WIPP-12 & 2483 & 0.120 & $11300^{\mathrm{b}}$ & \pm 600 \\
\hline WIPP-12 & 2483 & 0.113 & $10600^{\mathrm{b}}$ & \pm 600 \\
\hline WIPP-12 & 2483 & 0.118 & $11100^{b}$ & \pm 600 \\
\hline WIPP-12 & 2483 & 0.105 & $9900^{b}$ & \pm 600 \\
\hline WIPP-12 & 2483 & 0.107 & $10100^{\mathrm{b}}$ & \pm 600 \\
\hline WIPP-12 & 2741 & 0.088 & $8200^{b}$ & \pm 700 \\
\hline WIPP-12 & 2741 & 0.088 & $10000^{b}$ & \pm 3400 \\
\hline DOE-1 & 3374 & 0.104 & 9800 & \pm 700 \\
\hline DOE-1 & 3708 & 0.110 & 10400 & \pm 1100 \\
\hline DOE-1 & 3709 & 0.038 & 3400 & \pm 700 \\
\hline DOE-1 & 4031 & 0.036 & $3200^{b}$ & \pm 1300 \\
\hline DOE-1 & 4031 & 0.100 & $9400^{b}$ & \pm 1300 \\
\hline $\begin{array}{l}\text { a } 90 \% \text { conf } \\
\text { different } \\
\text { same fluic }\end{array}$ & $\begin{array}{l}\text { nce } \\
\text { id inclusions } \\
\text { aclusion }\end{array}$ & & & \\
\hline
\end{tabular}




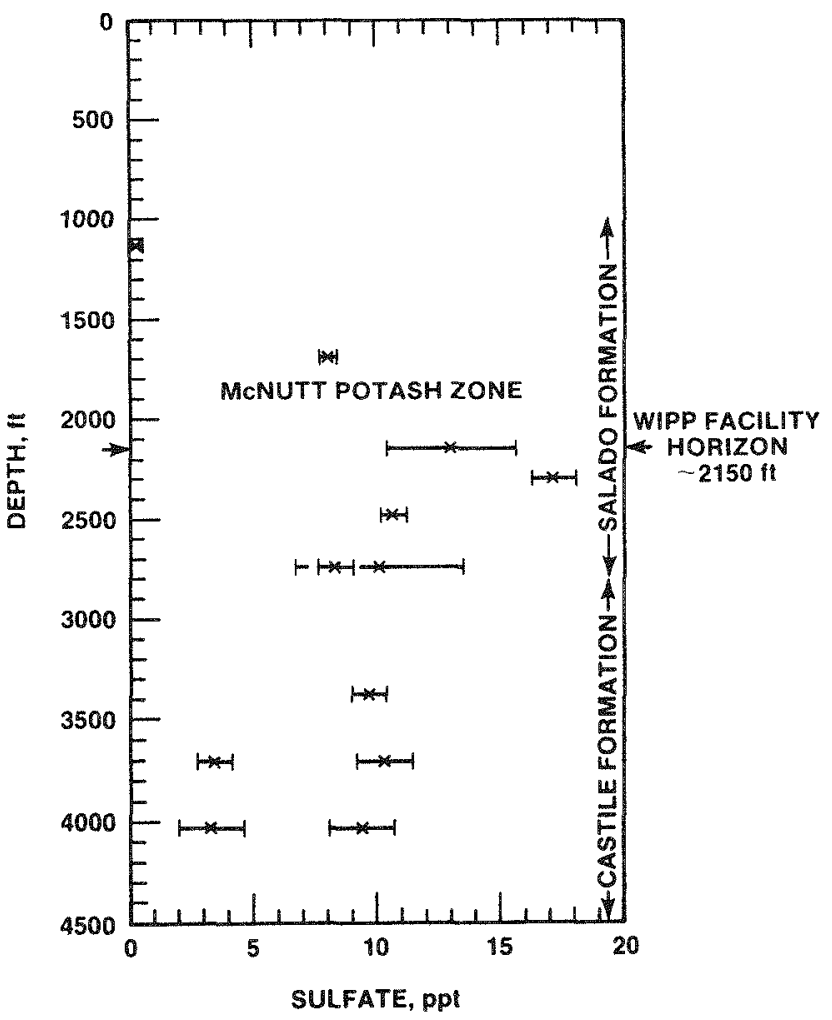

Figure 11. Laser Raman Spectroscopic Analyses of Samples From WIPP-12 and DOE-1. (The sulfate values, as determined by laser Raman spectroscopy, are plotted vs depth in the lower Salado and upper Castile Formations. Extended lines denote error bars.)

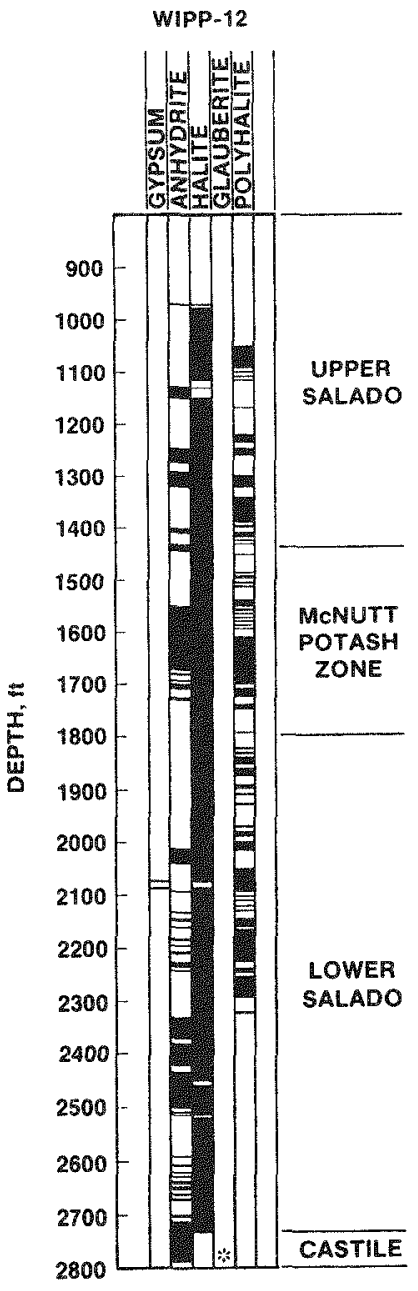

Figure 12. Lithology of WIPP-12. (Compiled from data in core description contained in Sandia Report SAND82-2336. The asterisk indicates approximate occurrence of primary glauberite according to Lowenstein, 1982.) 


\section{Discussion}

A profusion of papers has appeared in the geological literature dealing with the mineralogy, petrology, and geochemistry of halites from the Delaware Basin (Adams, 1965; Jones, 1972; Dean and Anderson, 1978; Anderson et al, 1978). The work of Roedder and Belkin (1979) contains what appears to be, to date, the most comprehensive summary of geochemical research on fluid inclusions from core samples taken at the WIPP site. Although their study was confined to samples only from ERDA-9, many of their conclusions are consistent with observations described in this study. To summarize briefly the points in common with this work:

1. The inclusion types most commonly seen in the WIPP samples described herein are primary; i.e., those in the configuration of hopper crystals-the Type A inclusions of Roedder and Belkin (1979); and those seen in clear, perhaps partly or completely recrystallized halite-the Type B inclusions of Roedder and Belkin (1979).

2. The amount of fluid contained in these inclusions as estimated by Roedder and Belkin (1979) is $\sim 1$ vol \%; the measurements reported in this study are in good agreement with theirs. However, as they report, fluid content is extremely variable and highly dependent on sample selection.

3. The wide range of freezing temperatures, as discussed in the following section, indicates considerable variation in fluid composition, even on a relatively small stratigraphic scale. Moreover, these liquids are not simple $\mathrm{NaCl}$ $\mathrm{H}_{2} \mathrm{O}$ solutions. Analytical work, to be the subject of a later report, already shows that some solutions contain 10 to $40 \mathrm{ppt} \mathrm{K}^{+}$and $\mathrm{Mg}^{2+}$, and/or lesser $\mathrm{Ca}^{2+}$, as well as $\mathrm{Na}^{+}, \mathrm{Cl}^{-}$, and $\mathrm{SO}_{4}^{2-}$. The effects of these cations on freezing temperatures of brines and on the stability behavior of the phases formed during freezing are poorly understood.

The freezing-point determinations presented here show a wide range, from $-44.1^{\circ} \mathrm{C}$ to $+3.9^{\circ} \mathrm{C}$. (A freezing point of $+3.9^{\circ} \mathrm{C}$ possibly results from the slow melting of hydrohalite, $\mathrm{NaCl} \cdot 2 \mathrm{H}_{2} \mathrm{O}$; Roedder, 1984.) There is no apparent correlation between freezing temperatures and sample depth in the formations, as seen in Figure 13. Also, the lack of any consistent trend with increasing depth tends to preclude a model involving the mixing of meteoric and intraformational waters. If such mixing has occurred and if inclusions then migrated to any significant extent because of the geothermal gradient or lithostatic pressure, one should expect the distribution of freezing temperatures to be more uniform.

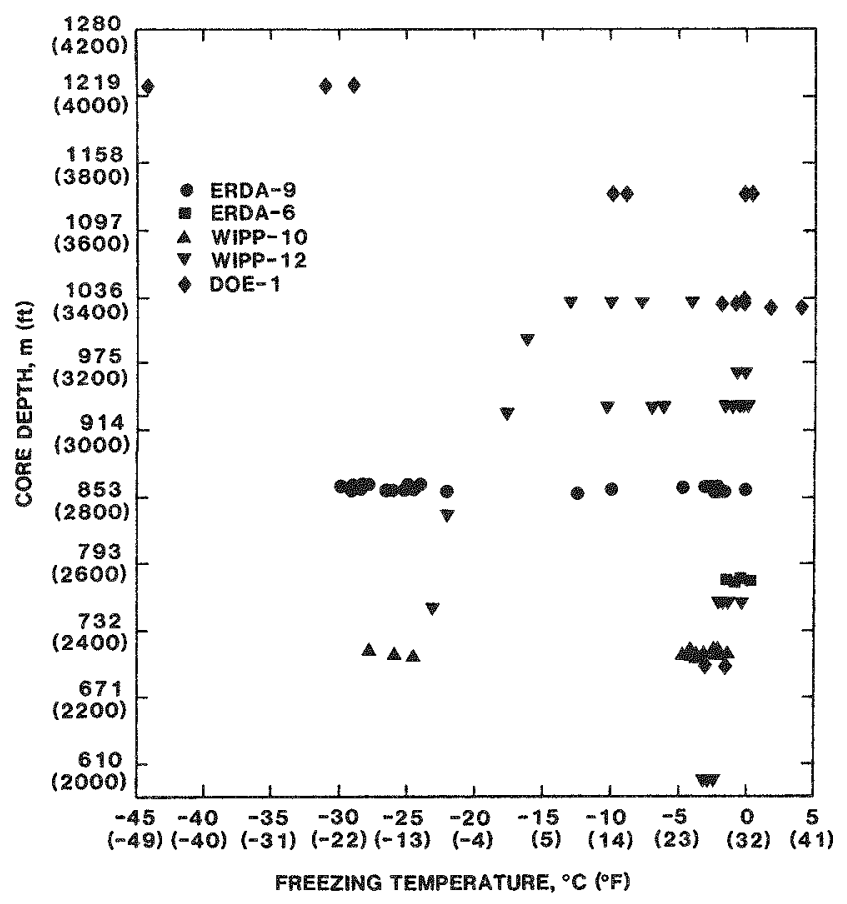

Figure 13. Plot of Fluid-Inclusion Freezing Temperatures (in ${ }^{\circ} \mathrm{C}$ ) vs Depth in the Lower Salado and Upper Castile Formations

However, the distribution of freezing temperatures appears to be related to the lithology (as seen in Figure 10). Although vague, this relationship is also consistent with fluid inclusions containing substantial amounts of other solutes- $\mathrm{K}^{+}, \mathrm{Mg}^{2+}$, and/or $\mathrm{Ca}^{2+}$, although the sulfate data and cation data were obtained from different inclusions. The tendency for fluid inclusions with extremely low freezing temperatures to be associated with halite-anhydrite contacts suggests that these fluids are representative of formation water composition at the time of deposition. This observation also indicates that the inclusions have not moved any great distance since their formation. Further, as Roedder and Belkin (1979) suggest, the abundance of fluid inclusions in the classic hopper-crystal configuration is assumed to signify original, or "primary," depositional texture. Even where halite recrystallization is evident, freezing-point measurements on both Type A and Type B inclusions (after Roedder's definition) show very little difference in the same hand specimen.

It was noted that, almost as a rule, halite crystals in the samples used in this study tended to become clearer, larger, and presumably more recrystallized 
with increased distance from anhydrite (e.g., at distances greater than several millimeters to several centimeters). Simultaneously, fluid inclusions tended to become larger but increasingly scarce. This inclusion volume increase may result from partial coalescence of the smaller inclusions that make up the hopper crystals. It is not yet known how or to what extent inclusions disappear when they contact grain boundaries. Future work, as discussed in the following section, addresses this problem.

The trend defined by the laser Raman spectroscopic analyses proved particularly interesting. It was disappointing to find that these analyses for dissolved $\mathrm{SO}_{4}^{2-}$ in fluid inclusions did not appear to correlate with freezing-point measurements as anticipated. However, the $\mathrm{SO}_{4}^{2-}$ values do show a reasonably consistent correlation with depth in this portion of the stratigraphic section above $\sim 2300 \mathrm{ft}$ (Figure 11). The split in dissolved sulfate values within Castile Formation samples remains problematical.

The rationale for the sample selection scheme is based on the expectation that fluid inclusions in close association with anhydrite, whether through original deposition (e.g., in situ inclusions) or by postdepositional migration, would exhibit some degree of equilibration with anhydrite, which would then be reflected in the $\mathrm{SO}_{4}^{2-}$ concentrations in the fluid inclusions. Using the $\mathrm{Ca}^{2+}$ values obtained by emission spectroscopy (from inclusions in the WIPP facility horizon, as described previously), together with data from Marshall et al (1964), we calculated $\mathrm{SO}_{4}^{2-}$ values for a fluid in equilibrium with anhydrite in a 5 -molar $\mathrm{NaCl}$ brine, e.g., comparable to WIPP brines.

These calculated values exceed those in the Castile by a factor of $\sim 3$; clearly, equilibration with anhydrite is not responsible for the 5 to $10 \mathrm{ppt} \mathrm{SO}_{4}^{2-}$ seen in these samples. Therefore, some other mechanism must be involved to explain the two distinct populations. They possibly represent fluid mixing and/or compositional modification by diagenetic reactions at some time in the past; currently, isotopic data are insufficient to prove this conclusively. However, this result does indicate that these inclusions have not migrated any significant distance-in particular, through the associated anhydrite beds or laminaebecause the fluids are substantially undersaturated with respect to equilibrium with anydrite.

The linear trend seen in the $\mathrm{SO}_{4}^{2-}$ analyses from the level of the facility horizon (at $2150 \mathrm{ft}$ ) and above is particularly noteworthy. This consistent decrease in fluid-inclusion $\mathrm{SO}_{4}^{2-}$ values going upward into the Salado Formation appears to coincide with the increasing abundance of polyhalite (Sandia Report
SAND82-2336), as seen in Figure 12. One possible hypothesis that may explain this observation is the alteration of gypsum or anhydrite to glauberite and then to polyhalite according to the following reactions (Harvie et al, 1980):

$$
\begin{aligned}
& \underset{\mathrm{CaSO}_{4}}{\mathrm{an}}+2 \mathrm{Na}^{+}+\mathrm{SO}_{4}^{2-} \rightarrow \mathrm{Na}_{2} \mathrm{Ca}\left(\mathrm{SO}_{4}\right)_{2} \\
& \mathrm{~K}_{\mathrm{sp}}=\frac{1}{\left(\mathrm{Na}^{+}\right)^{2}\left(\mathrm{SO}_{4}^{2-}\right)}
\end{aligned}
$$$$
\text { or, alternatively: }
$$$$
\text { gyp }
$$$$
2 \mathrm{CaSO}_{4} \cdot 2 \mathrm{H}_{2} \mathrm{O}+2 \mathrm{Na}^{+}+\mathrm{SO}_{4}^{2-}
$$

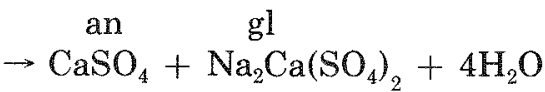$$
\mathrm{K}_{\mathrm{sp}}=\frac{1}{\left(\mathrm{Na}^{+}\right)^{2}\left(\mathrm{SO}_{4}^{2-}\right)}
$$$$
\text { gl an }
$$$$
\mathrm{Na}_{2} \mathrm{Ca}\left(\mathrm{SO}_{4}\right)_{2}+\mathrm{CaSO}_{4}+2 \mathrm{~K}^{+}+\mathrm{Mg}^{2+}+\mathrm{SO}_{4}^{2-}
$$$$
\text { poly }
$$$$
+2 \mathrm{H}_{2} \mathrm{O} \rightarrow \mathrm{K}_{2} \mathrm{MgCa}_{2}\left(\mathrm{SO}_{4}\right)_{4} \cdot 2 \mathrm{H}_{2} \mathrm{O}+2 \mathrm{Na}^{+}
$$$$
\mathrm{K}_{\mathrm{sp}}=\frac{\left(\mathrm{Na}^{+}\right)^{2}}{\left(\mathrm{~K}^{+}\right)^{2}\left(\mathrm{Mg}^{2+}\right)\left(\mathrm{SO}_{4}^{2-}\right)}
$$

This reaction of seawater with anhydrite and glauberite to form polyhalite appears to explain the depletion of seawater $\mathrm{SO}_{4}^{2-}$, as seen in the fluidinclusion analyses, as well as the appearance of polyhalite. In addition, if these reactions did indeed occur, the scarcity of glauberite in this portion of the stratigraphic section is also explained. Lowenstein (1982) does in fact report the primary occurrence of glauberite in lower Salado halite. He has observed randomly oriented glauberite crystals that are now replaced by anhydrite and halite. It is assumed, mainly from petrographic evidence, that these alteration reactions occurred at some time following deposition of this part of the formation.

In addition, this conclusion is based largely on analyses that were taken from both primary and secondary fluid inclusions. The distribution of sulfate values with depth appears to reflect a quasi-static equilibrium with a solution from which both halite and either gypsum or anhydrite were being deposited (e.g., the nearly constant but bimodal $\mathrm{SO}_{4}^{2-}$ values in primary inclusions from the Castile samples). The 
decrease in dissolved $\mathrm{SO}_{4}^{2-}$ (going upward in the lower Salado) is consistent with the appearance of polyhalite, assuming an origin for this mineral involving the alteration of glauberite and anhydrite. As the dissolved $\mathrm{SO}_{4}^{2-}$ analyses in the lower Salado are from unequivocally primary inclusions, one may conclude that these reactions must have occurred essentially contemporaneously with deposition of this part of the stratigraphic section. The uppermost samples, taken from secondary inclusions immediately adjacent to and above the McNutt Potash Zone, are most likely the result of postdepositional alteration, the relative timing of which is, as yet, undetermined.

\section{Plans for Future Work}

The general trends defined by the dissolved $\mathrm{SO}_{4}^{2-}$ values are thought to represent some degree of longterm evolution in the composition of seawater in the Delaware Basin. Further work is planned to clarify this point. Seven major topics either in progress or under consideration are described below.

1. Further fluid-inclusion analyses to complement those obtained thus far are potentially of great value. Specifically, it seems desirable to analyze fluid inclusions from halites immediately above, below, and intermixed with the McNutt Potash Zone. If these fluids in fact reflect either changing composition of basin water or secondary diagenetic alteration, the inclusion compositions should systematically reflect the associated mineralogy. The correlation of dissolved $\mathrm{SO}_{4}^{2-}$ with mineralogy appears to be a promising lead. Continued laser Raman spectroscopy is therefore expected to be a necessary part of future fluid-inclusion investigations. Also, the laser Raman technique may be a valuable tool for investigating dissolved gases (particularly hydrocarbons and related organic compounds) in inclusion fluids.

2. The emission spectroscopy of fluids from individual inclusions is being continued. The evidence obtained to date suggests that fluid inclusions may be grouped into distinct populations on the basis of elemental composition at the ppm level. Moreover, it may be possible to distinguish meteoric from marine fluids on the basis of the minor element composition, although this is also merely speculative at this point. In addition, it is hoped that fluid- inclusion compositions may be correlated with other waters found in the vicinity of the facility horizon (for example, the "weeps" occasionally seen on the mine walls).

3. It would be highly interesting to make determinations of freezing points and laser Raman analyses on fluid inclusions from some of the anhydrites in the Castile and lower Salado. These measurements would answer such questions as: Are these fluids similar to, or radically different from, those in adjacent anhydrite units? Does the additional information from anhydrite inclusions confirm or refute any of the previously described hypotheses for fluid origin?

4. Much experimental work has been planned for the purpose of investigating the mechanics of fluid-inclusion migration. These experiments will focus primarily on the phenomenon of pressure solution vs plastic deformation and on measurements of rate and direction of inclusion migration in a nonuniform stress field, including what happens when a fluid inclusion reaches a grain boundary.

5. Electron microprobe analyses have been completed by Division 1822 for selected samples. They showed that concentrations of major elements $\left(\mathrm{Ca}^{2+}, \mathrm{Mg}^{2+}\right.$, and $\left.\mathrm{K}^{+}\right)$in the halite do not change significantly in the immediate vicinity of fluid inclusions. Because of their geochemical importance and because these data are being requested by W. Wawersik (Div 1542) in an attempt to relate creep behavior in rock salt to impurities in the $\mathrm{NaCl}$ structure, additional efforts of this nature are planned.

6. As mentioned earlier, heating measurements were not made on these fluid inclusions as a matter of priority. However, it may be of interest to look at such analyses as a possible way to distinguish zones or episodes of halite deformation.

7. Stable isotope analyses of fluid inclusions from these samples would also be useful in distinguishing fluid origin and relative time(s) and temperature (s) of emplacement or mineral alteration. At present, it is anticipated that these analyses will eventually be performed with the new mass spectrometer facility under the direction of S. J. Lambert of Sandia National Laboratories Div 6331. 


\section{Conclusions}

In general, fluid-inclusion compositions in the Delaware Basin appear to be best represented by a $\mathrm{NaCl}$ brine. The plots shown in Figures 14 through 17 are based on groundwater data compiled by Lambert (1978) and show the relationships of $\mathrm{Ca}^{2+}$ to $\mathrm{SO}_{4}^{2-}$ and $\mathrm{K}^{+}, \mathrm{Mg}^{2+}$, and $\mathrm{Na}^{+}$to $\mathrm{Cl}^{-}$, respectively. Clearly, the only linear relationship is that of $\mathrm{Na}^{+}$to $\mathrm{Cl}^{-}$. Figure 17 also contains a point representing fluid-inclusion compositions from ERDA-6; $\mathrm{Na}^{+}$and $\mathrm{Cl}^{-}$are calculated from the equations given by Potter et al (1978) in Appendix $\mathrm{B}$ and the measured freezing temperatures. This point is nearly coincidental with the composition given for the brine reservoir found at ERDA-6. Thus it appears that, at least to a first approximation, the assumption of a $\mathrm{NaCl}-\mathrm{H}_{2} \mathrm{O}$ system for inclusion composition is valid.

However, both the laser Raman $\mathrm{SO}_{4}^{2-}$ analyses and those obtained to date by emission spectroscopy show that the fluid-inclusion chemistry is much more complex and therefore deserving of continued investigation as outlined in this report. Dissolved $\mathrm{SO}_{4}^{2-}$ analyses of samples from the brine reservoirs at ERDA-6 and WIPP-12 differ from the values for the same depths seen in Figure 11 by a factor of 2 . Thus the evidence obtained from the results of this study strongly suggests that water contained in the brine reservoirs encountered during preliminary drilling is unrelated to fluid-inclusion compositions. Further, the geochemical and petrographic evidence discussed here indicates that fluid inclusions in these halites are essentially in situ. Whether they are primary or the product of secondary alteration, it appears that they are, for the most part, situated in the location of their formation, with relatively little movement through the host rock.

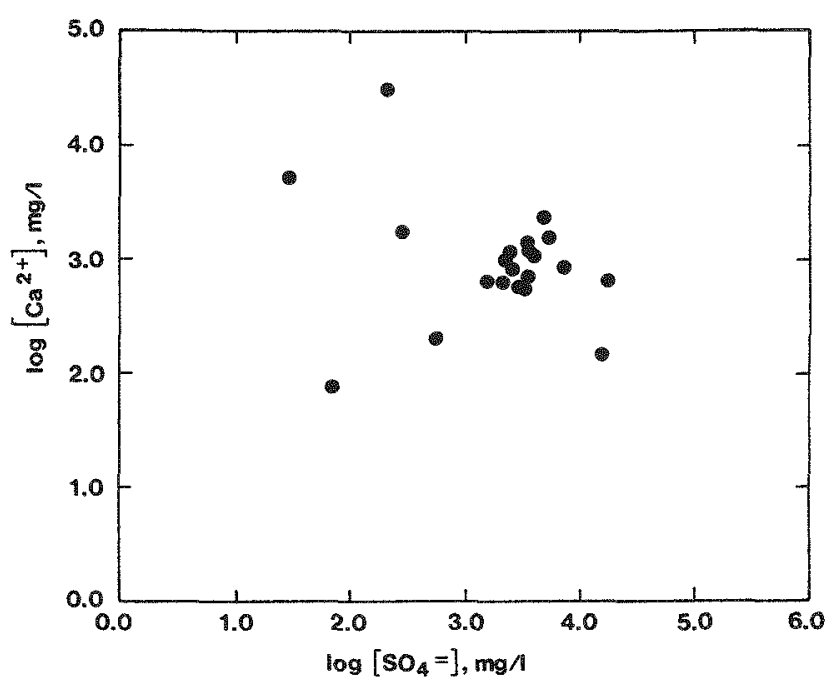

Figure 14. Composition of Delaware Basin Groundwater, $\log \left(\mathrm{Ca}^{2+}\right)$ vs $\log \mathrm{SO}_{4}^{2-}$. (From Lambert, 1978.)

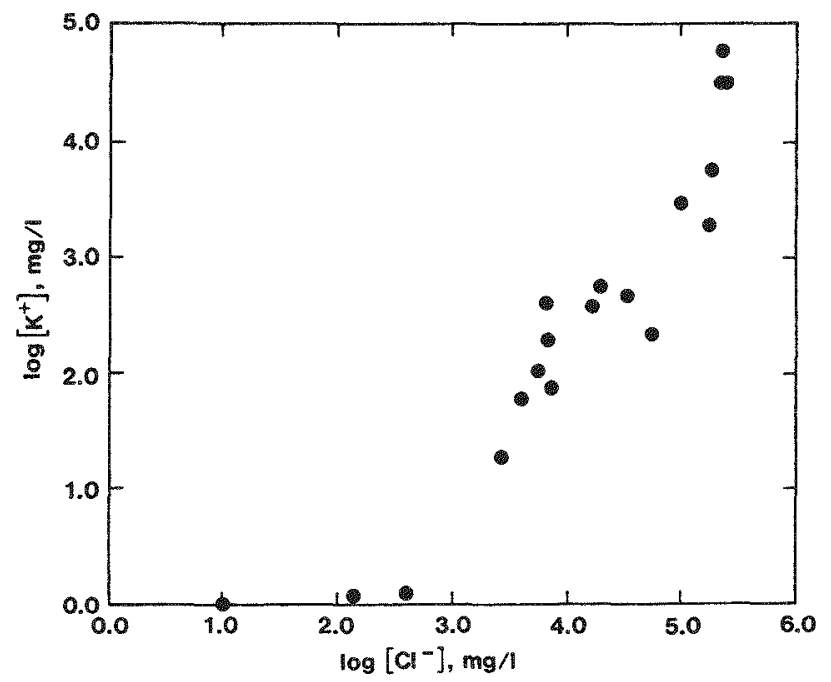

Figure 15. Composition of Delaware Basin Groundwater, $\log \left(\mathrm{K}^{+}\right)$vs $\log \left(\mathrm{Cl}^{-}\right)$. (From Lambert, 1978.) 


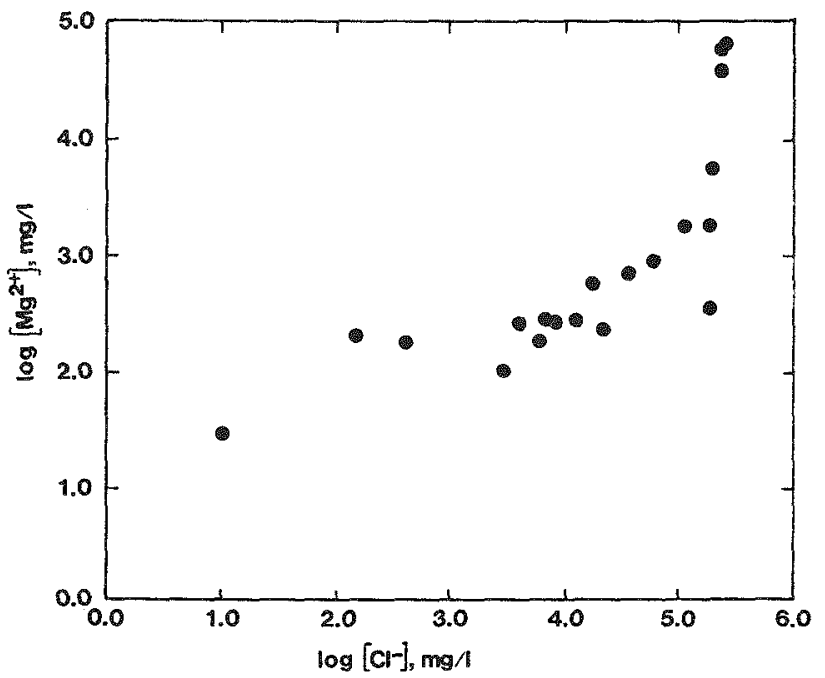

Figure 16. Composition of Delaware Basin Groundwater, $\log \left(\mathrm{Mg}^{2+}\right)$ vs $\log \left(\mathrm{Cl}^{-}\right)$. (From Lambert, 1978.)

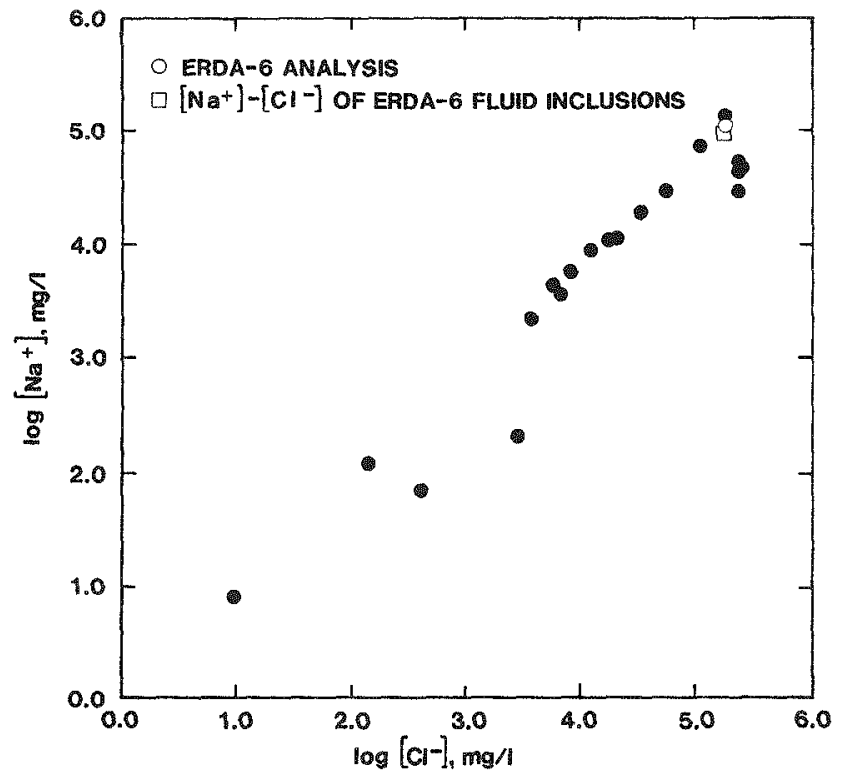

Figure 17. Composition of Delaware Basin Groundwater, $\log \left(\mathrm{Na}^{+}\right)$vs $\log \left(\mathrm{Cl}^{-}\right)$. (From Lambert, 1978. ERDA-6 fluid inclusion composition calculated from freezing-point measurements and the equations of Potter et al, 1978.) 



\section{Appendix A}

\section{Laser Raman Spectra}

\begin{tabular}{ll} 
Origin of Sample & $\begin{array}{l}\text { Depth of Sample } \\
\text { Below Surface (ft) }\end{array}$ \\
\hline WIPP-12 & 1125.2 to 1125.6 \\
WIPP-12 & 1692.4 to 1692.8 \\
Facility Horizon & 2150 \\
DOE-1 & 2297 \\
WIPP-12 & 2483 \\
WIPP-12 & 2741.5 to 2741.8 \\
DOE-1 & 3374 \\
DOE-1 & 3708 \\
DOE-1 & 3709 \\
DOE-1 & 4031 \\
WIPP-12, Salt Background & 2483
\end{tabular}

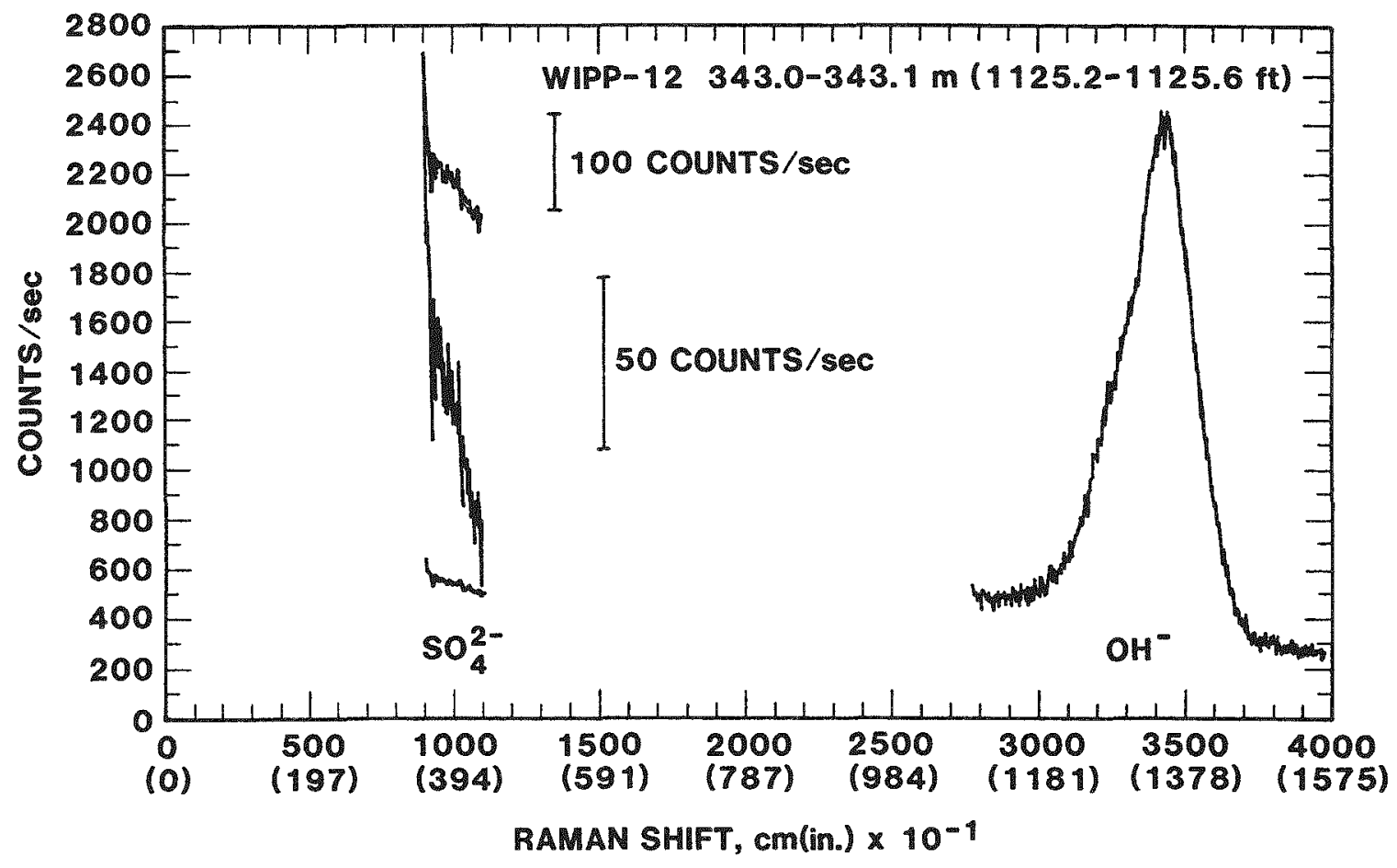

Figure A1. Sample from WIPP-12, 1125.2 to $1125.6 \mathrm{ft}$ 


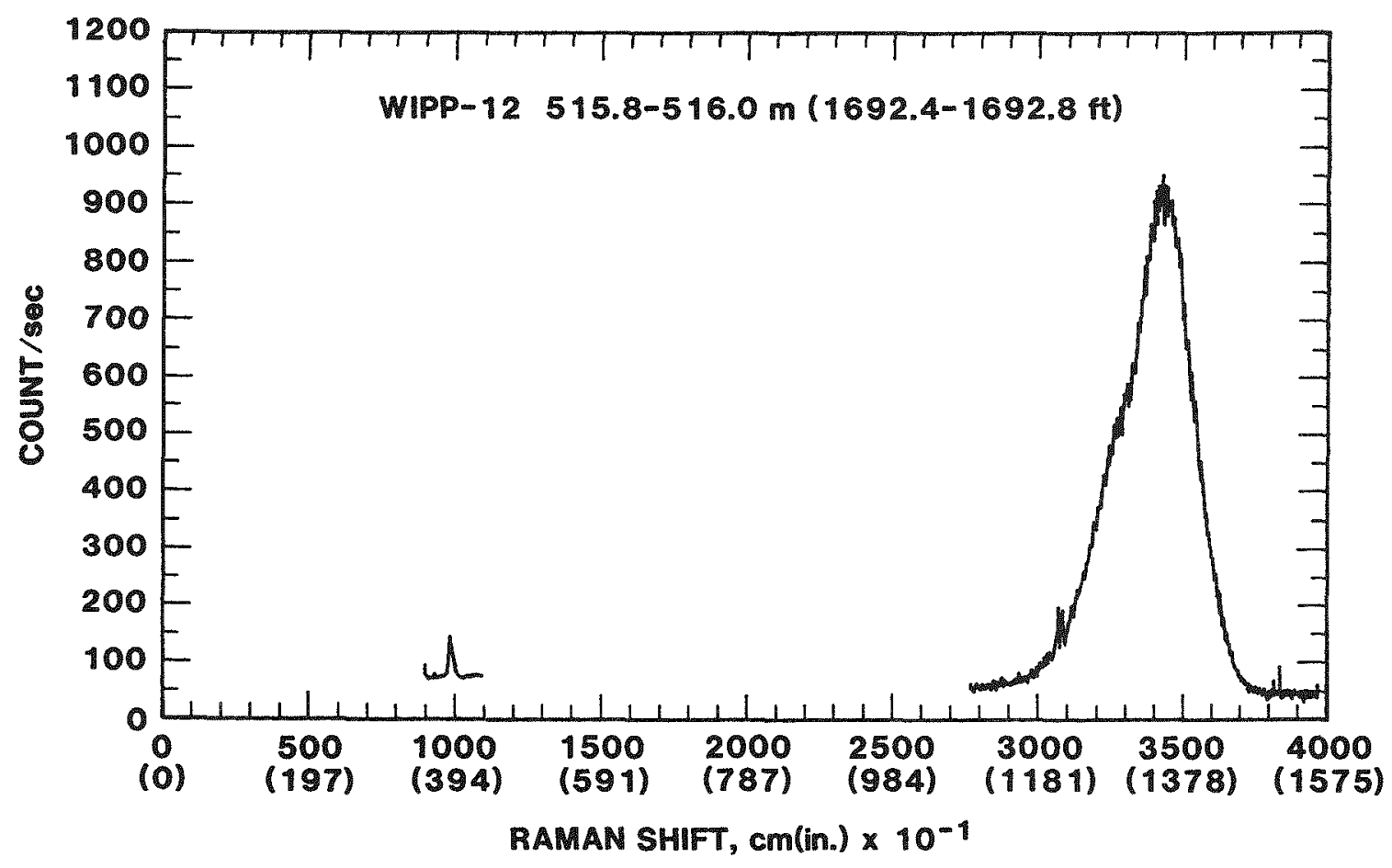

Figure A2. Sample from WIPP-12, 1692.4 to $1692.8 \mathrm{ft}$

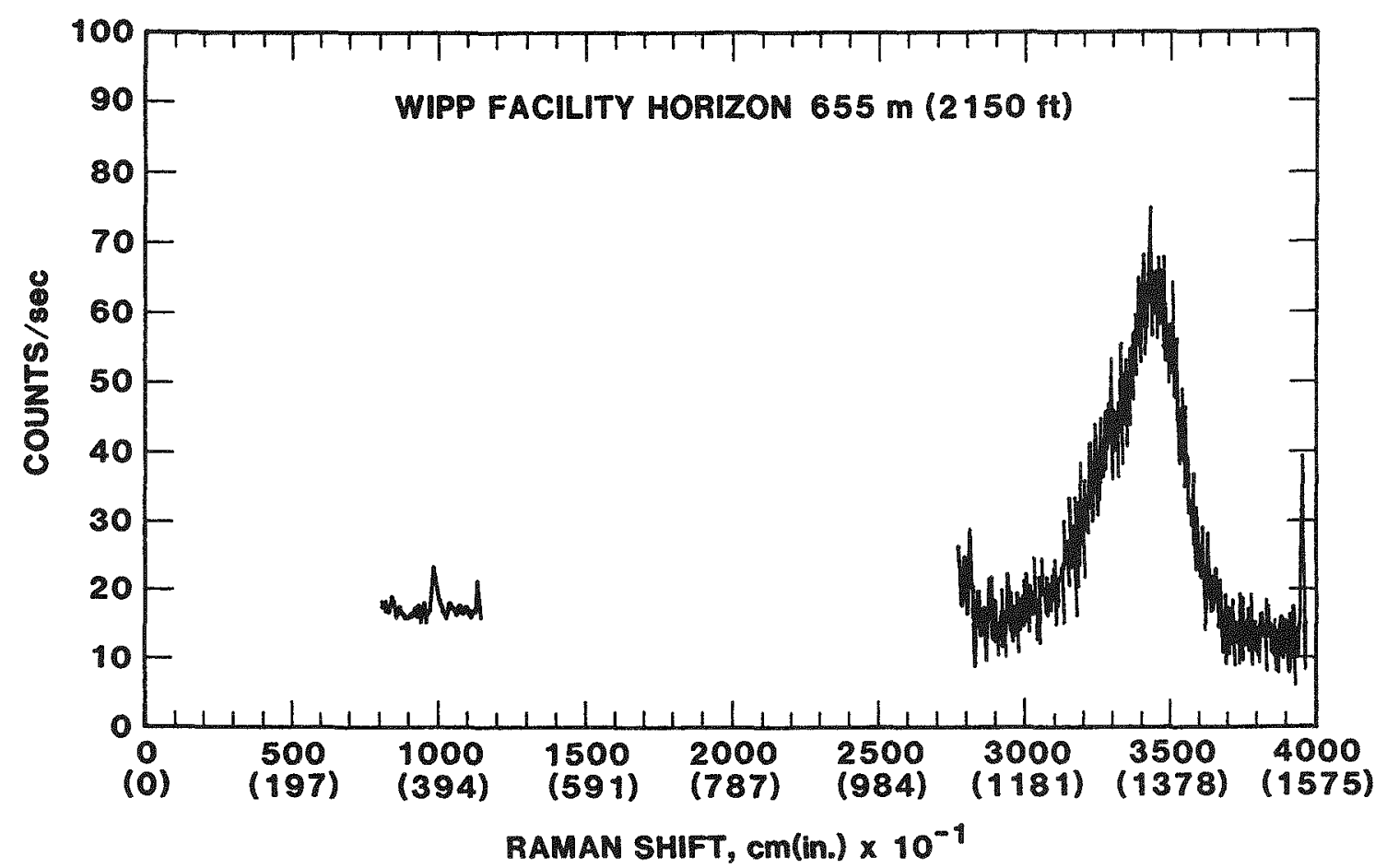

Figure A3. Sample from WIPP Facility Horizon, $2150 \mathrm{ft}$ 


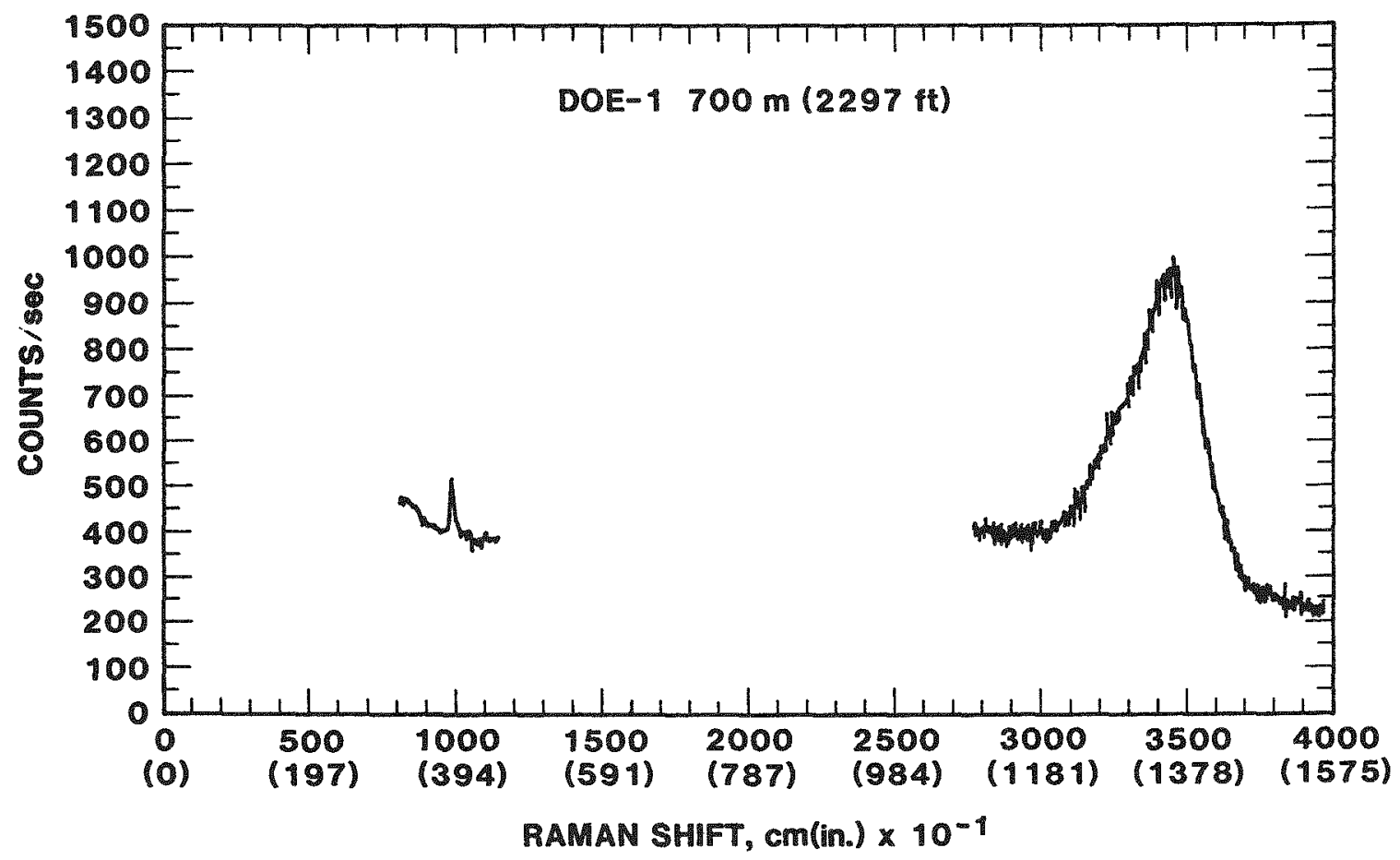

Figure A4. Sample from DOE-1, $2297 \mathrm{ft}$

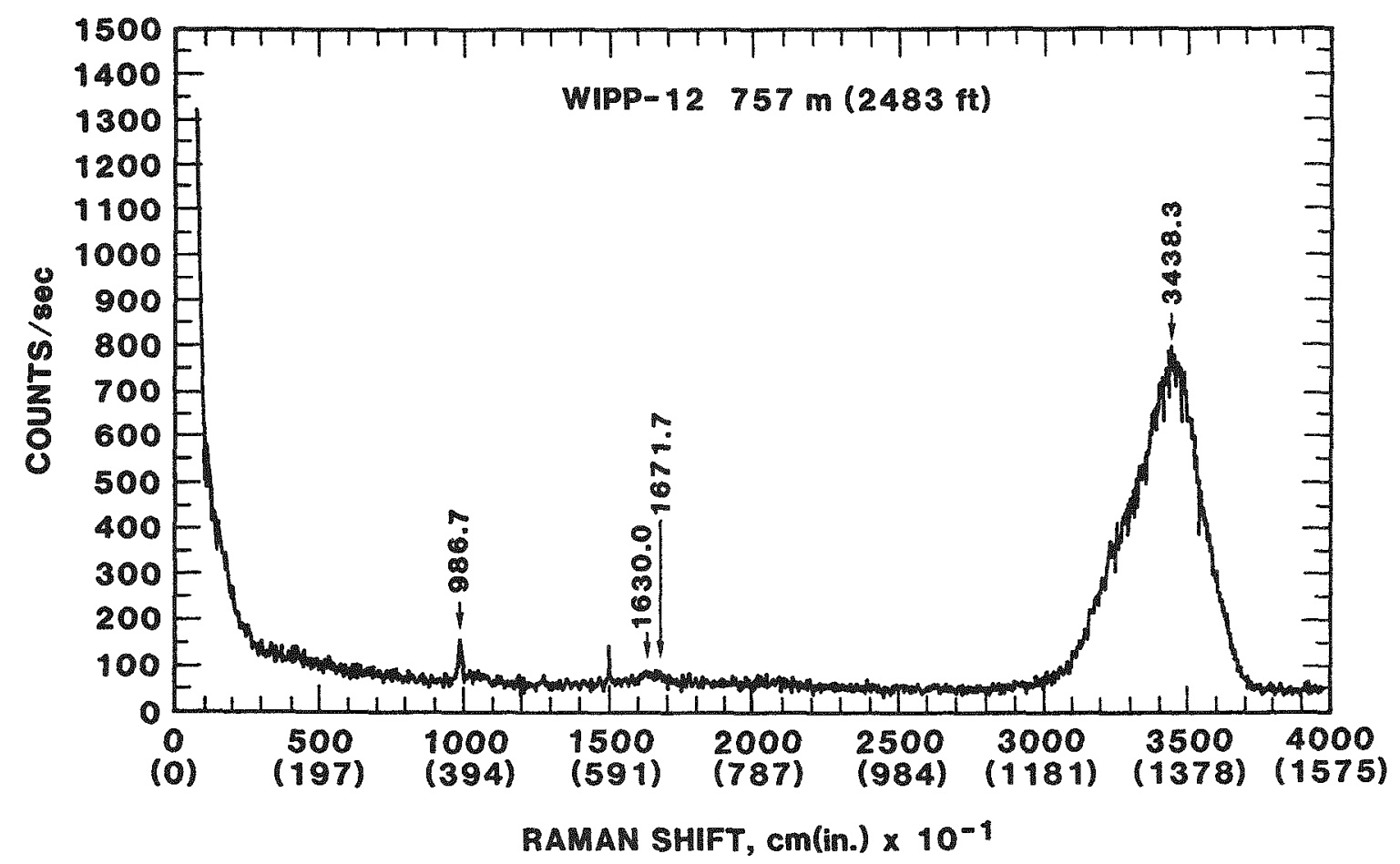

Figure A5. Sample from WIPP-12, $2483 \mathrm{ft}$ 


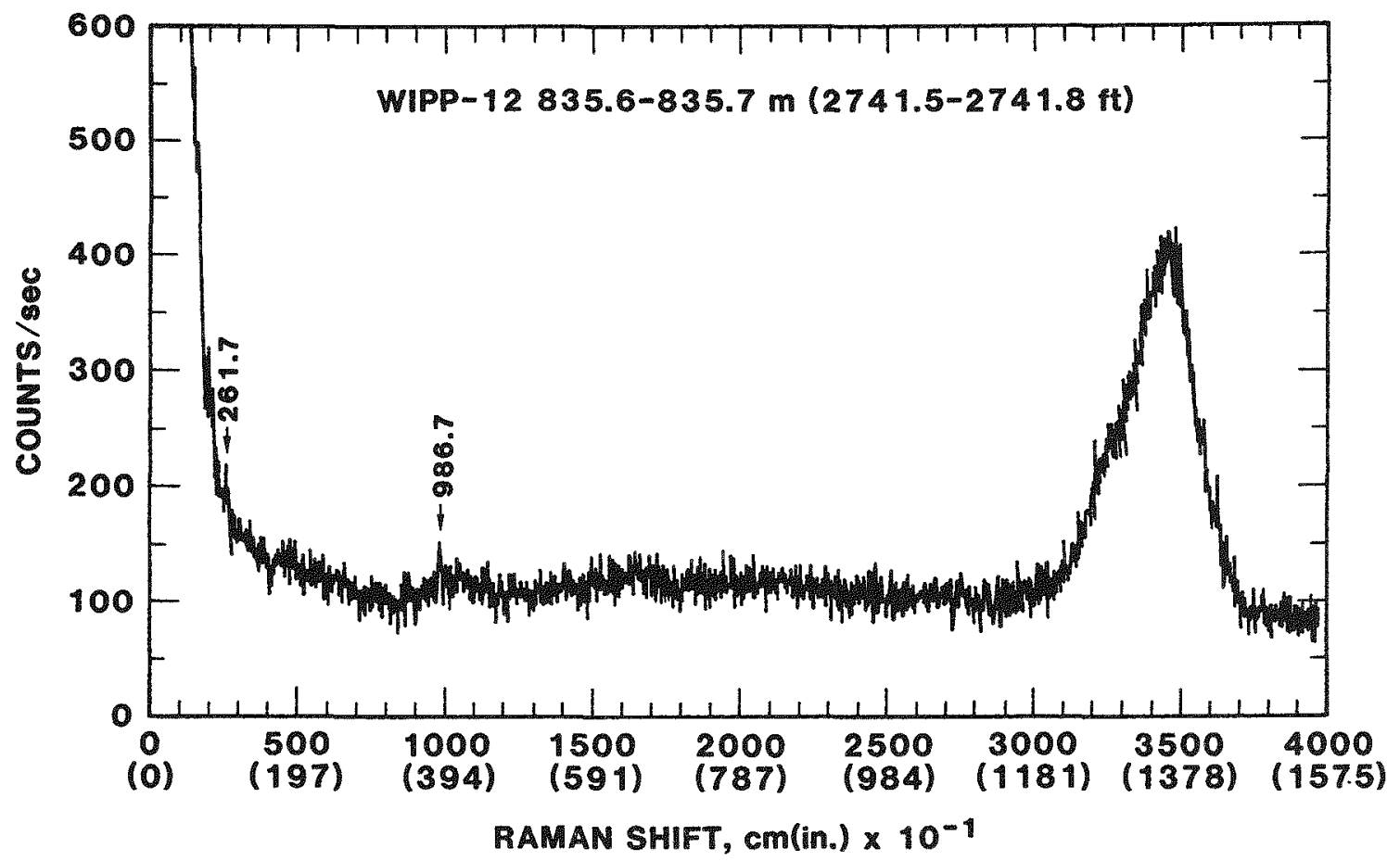

Figure A6. Sample from WIPP-12, 2741.5 to $2741.8 \mathrm{ft}$

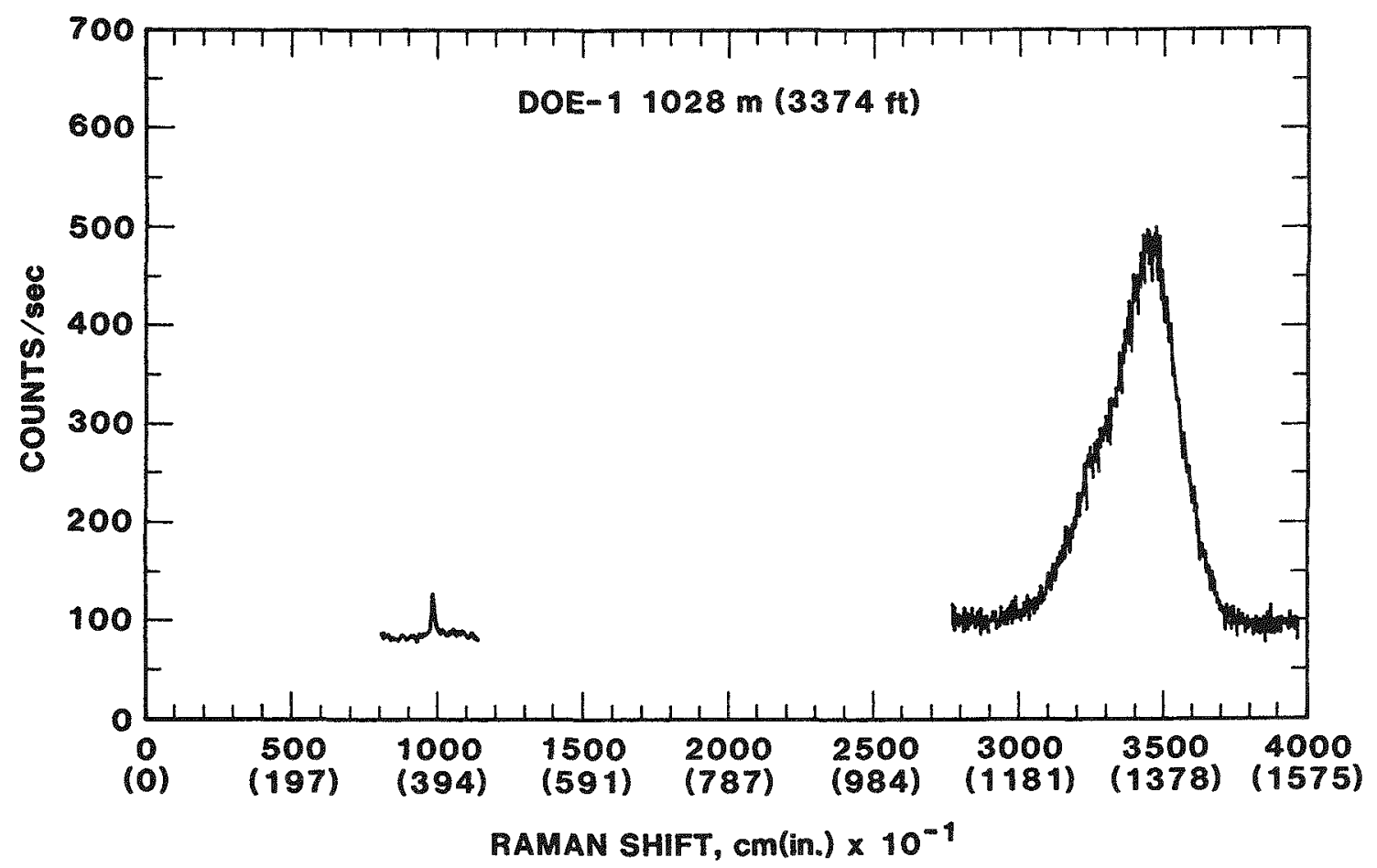

Figure A7. Sample from DOE-1, $3374 \mathrm{ft}$ 


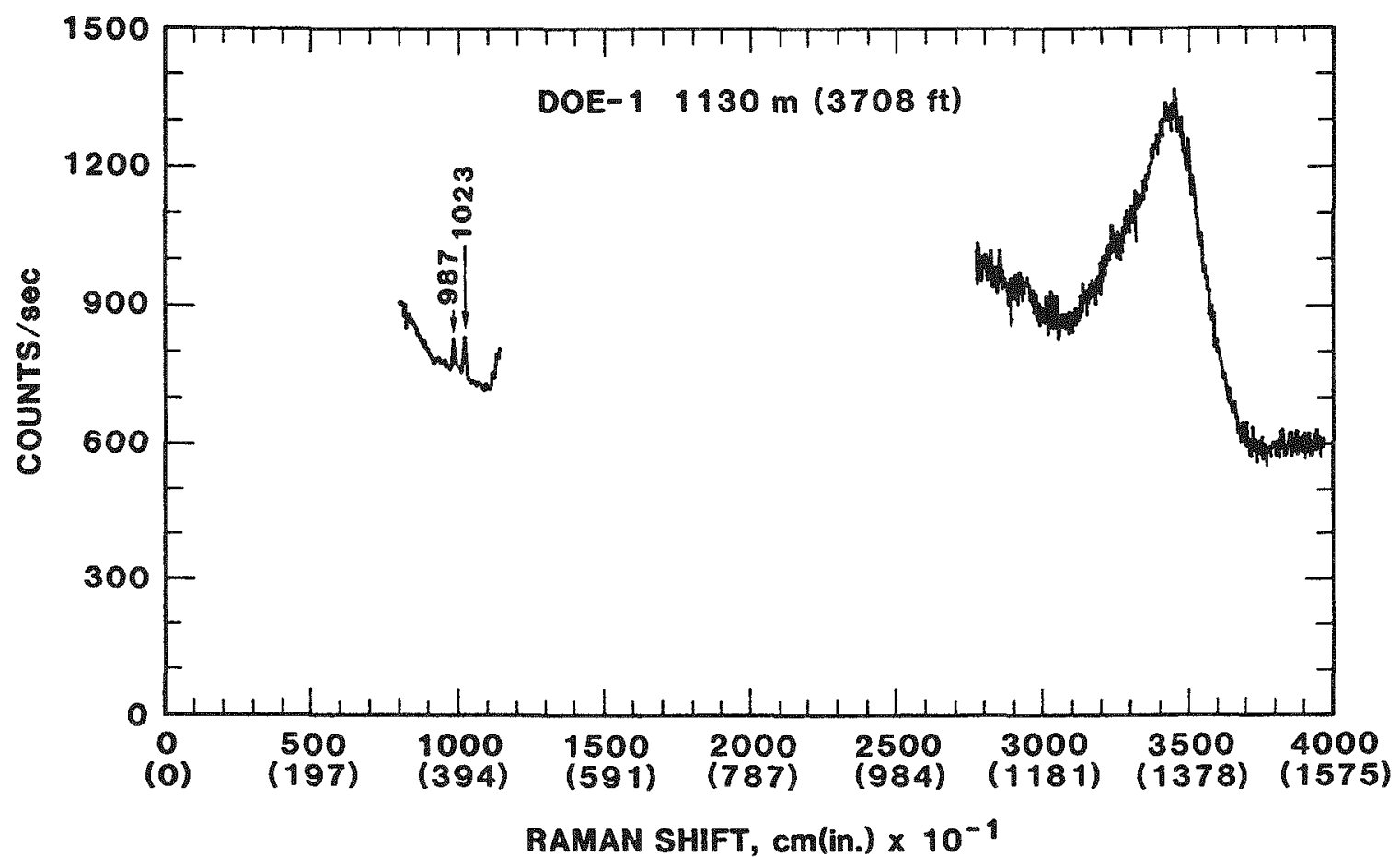

Figure A8. Sample from DOE-1, $3708 \mathrm{ft}$

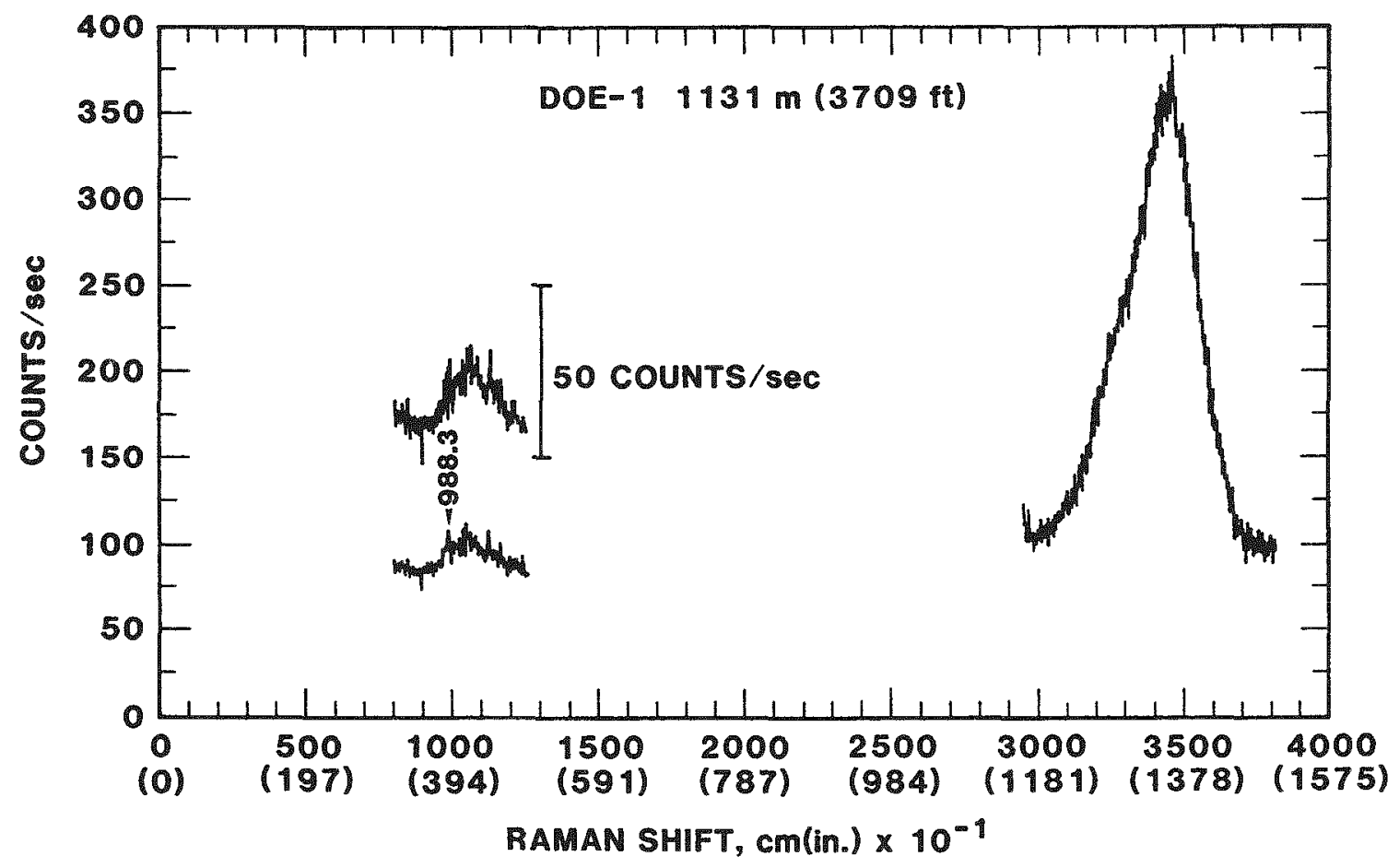

Figure A9. Sample from DOE-1, $3709 \mathrm{ft}$ 


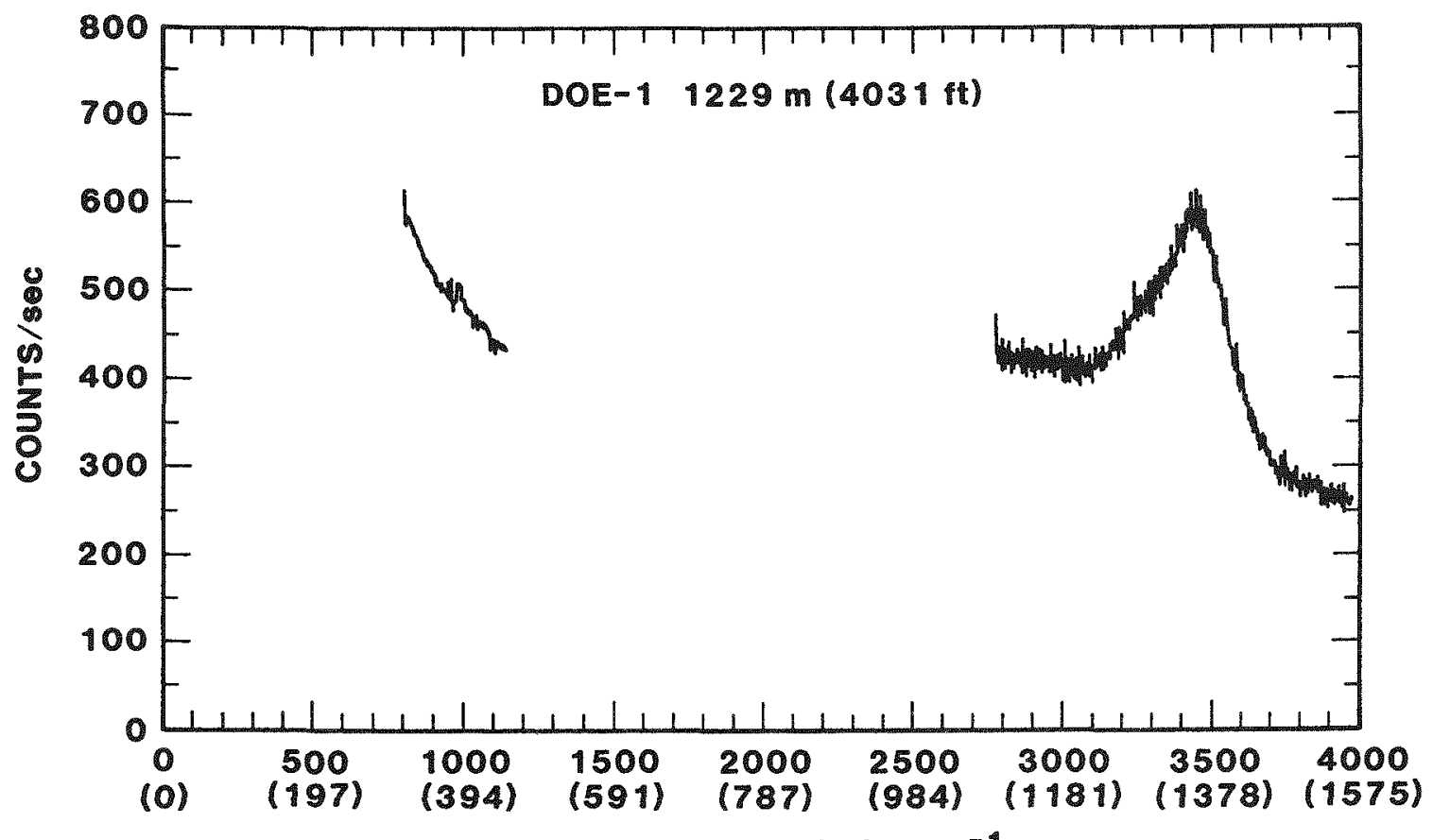

RAMAN SHIFT, cm(in.) $\times 10^{-1}$

Figure A 10. Sample from DOE-1, $4031 \mathrm{ft}$

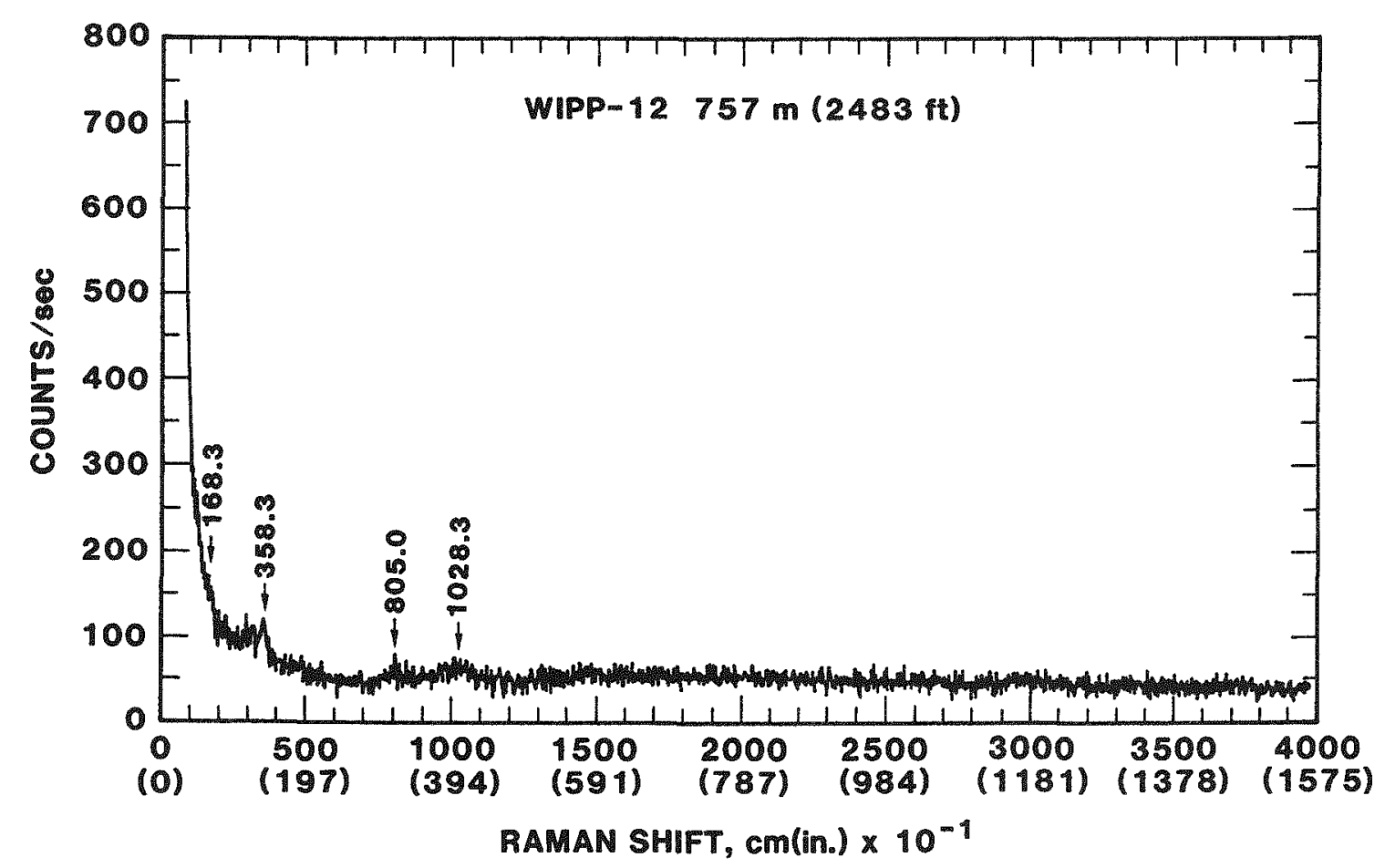

Figure A 11. Sample from WIPP-12, $2483 \mathrm{ft}$, salt background 


\section{Appendix B}

\section{Freezing-Point Calculations in $\mathrm{NaCl}$ Solutions} (from Potter et al, 1978)

$$
\begin{aligned}
& \mathrm{M}_{\mathrm{s}}= 0.00+0.30604 \theta-2.8598 \times 10^{-3} \theta^{2}+4.8690 \times 10^{-6} \theta^{3} \pm 0.007 \\
& \mathrm{~W}_{\mathrm{s}}= 0.00+1.76958 \theta-4.2384 \times 10^{-2} \theta^{2}+5.2778 \times 10^{-4} \theta^{3} \pm 0.028 \\
& \theta= 0.00+3.29325 \mathrm{M}_{\mathrm{s}}+0.07249 \mathrm{M}_{\mathrm{s}}+0.013185 \mathrm{M}^{3} \pm 0.03^{\circ} \\
& \theta= 0.00+0.581855 \mathrm{~W}_{\mathrm{s}}+3.48896 \times 10^{-3} \mathrm{~W}_{\mathrm{s}}^{2}+4.314 \times 10^{-4} \mathrm{~W}_{\mathrm{s}}^{3} \pm 0.03^{\circ} \\
& \text { where } \\
& \theta=\left.0-\text { freezing point (in }{ }^{\circ} \mathrm{C}\right) \\
& \mathrm{M}_{\mathrm{s}}=\text { molality of } \mathrm{NaCl} \text { in solution } \\
& \mathrm{W}_{\mathrm{s}}=\text { weight \% } \mathrm{NaCl} \text { in solution }
\end{aligned}
$$




\section{References}

J. E. Adams, "Stratigraphic-Tectonic Development of Delaware Basin," AAPG Bull 40:11, 2140-48 (1965).

R. Y. Anderson, K. K. Kietzke, and D. J. Rhodes, "Development of Dissolution Breccias, Northern Delaware Basin, New Mexico and Texas," New Mexico Bur of Mines and Mineral Resources, Circ 159, pp 47-52 (1978).

R. Bodnar, Chevron Oil Field Research, La Habra, CA (personal communication, 1983).

D. J. Borns, Petrographic Study of Evaporite Deformation Near the Waste Isolation Pilot Plant (WIPP), SAND83-0166 (Albuquerque, NM: Sandia National Laboratories, 1983).

J. Callender and T. Ingwell, Structural Petrology of Undeformed and Experimentally Deformed Halite Samples From USERDA \#7 and \#9, SAND78-7076 (Albuquerque, NM: Sandia National Laboratories, 1978).

N. L. Carter and F. D. Hansen, "Creep of Rocksalt," Tectonophys 92:275-333 (1983).

W. E. Dean and R. Y. Anderson, "Salinity Cycles: Evidence for Subaqueous Deposition of Castile Formation and Lower Part of Salado Formation, Delaware Basin, Texas and New Mexico," New Mexico Bur of Mines and Mineral Resources, Circ 159, pp 15-20 (1978).

J. Dubessy, D. Geisler, C. Kosztolanyi, and M. Vernet, "The Determination of Sulfate in Fluid Inclusions Using the M.O.L.E. Raman Microprobe, Application to a Keuper Halite and Geochemical Consequences, Geochim Cosmochim Acta 47:1-10 (1983).

M. H. Freeland, Basic Data Report for Borehole DOE-1, Dept. of Energy TME 3159 (Washington, DC: US DOE, 1982).

C. E. Harvie, J. H. Weare, L. A. Hardie, and H. P. Eugster, "Evaporation of Seawater: Calculated Mineral Sequences," Science 208:498-500 (1980).

C. L. Jones, "Permian Basin Potash Deposits, Southwestern United States," in: Geology of Saline Deposits: UNESCO, Earth Sci Ser No. 7:191-201 (1972).

S. J. Lambert, Dissolution of Evaporites In and Around the Delaware Basin, Southeastern New Mexico and West Texas, SAND82-0461 (Albuquerque, NM: Sandia National Laboratories, 1983).

S. J. Lambert, "Geochemistry of Delaware Basin Groundwaters," New Mexico Bur of Mines and Mineral Resources, Circ 159, pp 33-38 (1978).

T. Lowenstein, "Primary Features in a Potash Evaporite Deposit, the Permian Salado Formation of West Texas and New Mexico," in Depositional and Diagenetic Spectra of Evaporites-A Core Workshop: C. R. Handford, R. G. Loucks, and G. R. Davies, ed, SEPM Core Workshop No. 3 (Calgary, Canada, June 26-27, 1982), pp 276-304.
W. L. Marshall, R. Slusher, and E. V. Jones, "Solubility and Thermodynamic Relationships for $\mathrm{CaSO}_{4}$ in $\mathrm{NaCl}-\mathrm{H}_{2} \mathrm{O}$ Solutions from $40^{\circ} \mathrm{C}$ to $200^{\circ} \mathrm{C}, 0$ to 4 molal $\mathrm{NaCl}, " J$ Chem Eng Data 9(2):187-91 (1964).

R. W. Potter, M. A. Clynne, and D. L. Brown, "Freezing Point Depressions of Aqueous NaCl Solutions," Econ Geol 73:284-85 (1978).

J. K. Register, Brine Pocket Occurrences in the Castile Formation, Southeastern New Mexico, TME 3080 (Washington, DC: US DOE, 1981).

E. Roedder, "Studies of Fluid Inclusions, In Low Temperature Application of A Dual-Purpose Freezing and Heating Stage," Econ Geol 57:1045-61 (1962).

E. Roedder, US Geological Survey, Reston, VA (personal communication, 1984).

E. Roedder and R. L. Bassett, "Problems in Determination of the Water Content of Rock Salt Samples and Its Significance in Nuclear-Waste Storage Siting," Geol 9:525-30 (1981)

E. Roedder and H. E. Belkin, "Application of Studies of Fluid Inclusions in Permian Salado Salt, New Mexico, To Problems of Siting the Waste Isolation Pilot Plant," in G. J. McCarthy, ed, Scientific Basis for Nuclear Waste Management 1:313-21 (1979).

G. J. Rosasco and E. Roedder, "Application of A New Raman Microprobe Spectrometer to Nondestructive Analysis of Sulfate and Other Ions in Individual Phases in Fluid Inclusions in Minerals," Geochim et Cosmochim Acta 43:1907-15 (1979).

Sandia National Laboratories and US Geological Survey, Basic Data Report for Drillhole ERDA-6 (Waste Isolation Pilot Plant - WIPP), SAND79-0267 (Albuquerque, NM: Sandia National Laboratories, 1983).

Sandia National Laboratories and US Geological Survey, Basic Data Report for Drillhole ERDA-9 (Waste Isolation Pilot Plant - WIPP), SAND79-0270 (Albuquerque, NM: Sandia National Laboratories, 1983).

Sandia National Laboratories and D'Appolonia Consulting Engineers, Basic Data Report for Drillhole WIPP-12 (Waste Isolation Pilot Plant - WIPP), SAND82-2336 (Albuquerque, NM: Sandia National Laboratories, 1982).

C. L. Stein and J. L. Krumhansl, Chemistry of Brines in Rock Salt From the WIPP Site, Southeastern New Mexico (manuscript in preparation).

D. R. Tallant, K. L. Higgins, and C. L. Stein, Raman Microscopy Through Transparent Materials, SAND83-0373 (Albuquerque, NM: Sandia National Laboratories, 1983).

R. C. Weast, ed, Handbook of Chemistry and Physics, 54th ed (Cleveland, OH: Chemical Rubber Co Press, 1974). 


\section{DISTRIBUTION:}

US Department of Energy, Headquarters (2) Office of Nuclear Waste Management

Attn: A. Follett, Project Coordinator (WIPP) R. Stein

Washington, DC 20545

US Department of Energy (2)

Albuquerque Operations Office

Attn: G. C. Romatowski

D. G. Jackson, Dir, Public Affairs Div

PO Box 5400

Albuquerque, NM 87185

US Department of Energy (6)

Attn: W. R. Cooper Carlsbad WIPP Project Office (2)

A. Hunt, WPO (Carlsbad) (4)

PO Box 3090

Carlsbad, NM 88221

US Department of Energy

Carlsbad WIPP Project Office

Room 113, Federal Bldg

Carlsbad, NM 88220

US Department of Energy, NPO (2)

Office of Nuclear Waste Isolation

Attn: Jeff $O$. Neff

R. Wunderlich

505 King Ave

Columbus, $\mathrm{OH} 43201$

US Department of Energy

Richland Operations Office

Nuclear Fuel Cycle and Production Div

Attn: R. E. Gerton

PO Box 500

Richland, WA 99352

US Department of Energy

Research and Tech Support Div

Attn: D .E. Large

PO Box $\mathbf{E}$

Oak Ridge, TN 37830

US Department of Energy (2)

Division of Waste Products

Attn: G. H. Daly

J. E. Dieckhoner

Mail Stop B-107

Washington, DC 20545
US Department of Energy (2)

Idaho Operations Office

Nuclear Fuel Cycle Div

Attn: R. M. Nelson

$$
\text { J. Whitsett }
$$

550 Second St

Idaho Falls, ID 83401

US Department of Energy (4)

Savannah River Operations Office

Waste Management Project Office

Attn: J. R. Covell

D. Fulmer

S. Cowan

W. J. Brumley

PO Box A

Aiken, SC 29801

US Nuclear Regulatory Commission (3)

Division of Waste Management

Attn: Michael Bell

Hubart Miller

Jacob Philip

Mail Stop 697SS

Washington, DC 20555

US Nuclear Regulatory Commission

HLW Licensing Branch, Materials Section

Attn: F. R. Cook

MS 905 SS

Washington, DC 20555

Battelle Memorial Inst (17)

Project Management Div

Attn: W. Carbiener, General Manager (3)

S. Basham

D. E. Clark

S. Goldsmith

J. E. Hanley

P. Hoffman

H. R. Hume

H. N. Kalia

J. Kircher

S. Matthews

D. Moak

J. Moody

G. Raines

J. Treadwell

ONWI Library

505 King Ave

Columbus, $\mathrm{OH} 43201$ 


\section{DISTRIBUTION (cont):}

Battelle Pacific Northwest Labs (4)

Attn: D. J. Bradley

J. Relyea

R. P. Turcotte

R. E. Westerman

Battelle Blvd

Richland, WA 99352

Westinghouse Electric Corp (9)

Attn: P. Miskimin

V. Likar

L. Cole

V. DeJong

R. Gehrman

J. Johnson

J. W. Sadler

J. E. Stumbaugh

Library

PO Box 2078

Carlsbad, NM 88221

Bechtel, Inc (5)

Attn: E. Weber

H. Taylor

P. Frobenius

D. L. Wu

W. T. Li

45-11-B34

PO Box 3965

San Francisco, CA 94119

Oak Ridge National Lab (4)

Attn: R. E. Blanko

E. Bondietti

C. Claiborne

G. H. Jenks

PO Box Y

Oak Ridge, TN 37830

Oak Ridge National Lab

Attn: John O. Blomeke

PO Box X

Oak Ridge, TN 37830

US Geological Survey

Water Resources Div

Attn: John D. Bredehoeft, Western Region Hydrologist

345 Middlefield Rd

Menlo Park, CA 94025
Dr. Karl P. Cohen

928 N California Ave

Palo Alto, CA 94303

Stanford University

National Acad. of Sci., WIPP Panel

Dept. of Geology

Attn: Konrad B. Krauskopf, Chairman

Palo Alto, CA 94305

Vanderbilt University

Dept. of Environmental and Water Resources Engineering

Attn: Frank L. Parker, Vice Chm.

Nashville, TN 37235

University of Florida

Department of Material Sciences and Engineering

Attn: Fred M. Ernsberger, Adjunct Professor

Gainesville, FL 32611

Johns Hopkins University

Department of Earth Sciences

Attn: Hans P. Eugster

Baltimore, MD 21218

University of New Mexico

Department of Geology

Attn: Rodney C. Ewing

Albuquerque, NM 87131

University of Minnesota

Department of Geological Sciences

Attn: Charles Fairhurst

Minneapolis, MN 55455

University of Texas at Austin

Department of Geological Sciences

Attn: William R. Muehlberger

Austin, TX 78712

D'Arcy A. Shock

233 Virginia

Ponca City, OK 74601

National Academy of Sciences

Committee on Radioactive Waste Management

Attn: John T. Holloway, Senior Staff Officer

2101 Constitution Ave, NW

Washington, DC 20418 


\section{DISTRIBUTION (cont):}

Hobbs Public Library

Attn: Marcia Lewis, Librarian

509 N. Ship St

Hobbs, NM 88248

NM Inst of Mining/Tech

Martin Speere Memorial Library

Campus St

Socorro, NM 87810

New Mexico State Library

Attn: Ingrid Vollenhofer

PO Box 1629

Santa Fe, NM 87503

University of New Mexico

Zimmerman Library

Attn: Zanier Vivian

Albuquerque, NM 87131

WIPP Public Reading Room

Attn: Gwynn Schreiner

Atomic Museum, Kirtland AFB, East

Albuquerque, NM 87185

WIPP Public Reading Room

Carlsbad Municipal Library

Attn: Lee Hubbard, Head Librarian

101 S Hallagueno St

Carlsbad, NM 88220

Thomas Brannigan Library

Attn: Don Dresp, Head Librarian

$106 \mathrm{~W}$ Hadley St

Las Cruces, NM 88001

Roswell Public Library

Attn: Nancy Langston

301 N Pennsylvania Ave

Roswell, NM 88201

State of New Mexico (2)

Environmental Evaluation Group

Attn: Robert H. Neill, Dir

PO Box 968

Santa Fe, NM 87503

NM Department of Energy and Minerals (2)

Attn: Larry Kehoe, Secretary

Kasey LaPlante, Librarian

PO Box 2770

Santa Fe, NM 87501
Argonne National Lab (5)

Attn: S. Fried
A. M. Friedman
D. Hambeley
N. Meldgin
M. Steindler

9700 S Cass Ave

Argonne, IL 60439

Brookhaven National Lab (2)

Attn: P. Colombo, Dept of Applied Sciences

Cal Brewster, Bldg 830

Upton, NY 11973

Brookhaven National Lab

Associated Universities, Inc

Attn: Paul W. Levy, Senior Scientist

Upton, NY 11973

IT Corp (4)

Attn: P. Kelsall

R. McKinney

A. Moss

D. Shukla

Suite 306

2350 Alamo, SE

Albuquerque, NM 87106

E. I. Dupont de Nemours Co (4)

Attn: N. Bibler

E. J. Hennelly

M. J. Plodinec

G. G. Wicks

Savannah River Lab

Aiken, SC 29801

E. I. Dupont de Nemours Co

Attn: R. Baxter

Savannah River Plant

Aiken, SC 29801

Oak Ridge National Laboratory, Bldg. 2001

Ecological Sciences Information Center

Attn: C. S. Fore

PO Box X

Oak Ridge, TN 37830

Texas A\&M University

Center of Tectonophysics

Attn: John Handin

College Station, TX 77840 


\section{DISTRIBUTION (cont):}

J. F. T. Agapito Assoc, Inc

Attn: Christopher St. John

715 Horizon Dr, Suite 340

Grand Junction, CO 81501

Science Applications, Inc

Attn: D. E. Maxwell

2450 Washington Ave, Suite 120

San Leandro, CA 94577

Los Alamos National Lab

Attn: B. Erdal, CNC-11

PO Box 1663

Los Alamos, NM 87545

Rockwell International (3)

Atomics International Div

Attn: M. J. Smith

W. W. Schultz

P. Salter

Rockwell Hanford Operations

PO Box 800

Richland, WA 99352

US Department of Interior

Geological Survey

Attn: E. Roedder

959 National Center

Reston, VA 22092

Serata Geomechanics

Attn: Dr. Shosei Serata

4124 Lakeside Dr

Richmond, CA 94806-1941

Systems, Science, and Software (2)

Attn: P. Lagus

E. Peterson

Box 1620

La Jolla, CA 92038

Titanium Metals Corp of America

Henderson Technical Lab

Attn: R. W. Schulz

PO Box 2128

Henderson, NV 89015
US Army Engineers (8)

Waterways Experiment Station

Attn: D. Ainsworth

J. Armstrong

J. Boa

A. Buck

K. Mather

C. Pace

L. Wakeley

D. Walley

PO Box 631

Vicksburg, MS 39180

University of Arizona

Department of Mining and Geological Engineering

Attn: J. J. K. Daemen

Tucson, AZ 85721

University of New Mexico

Geology Department

Attn: D. G. Brookins

Albuquerque, NM 87131

Cornell University

Department of Physics

Attn: Dr. R. O. Pohl

Clark Hall

Ithaca, NY 14853

Cornell University

Department of Mechanical and Aerospace Engineering

Attn: Dr. Paul R. Dawson

254 Upson Hall

Ithaca, NY 14853

University of Minnesota

Department of Energy

and Materials Science

Attn: R. Oriani

151 Amundson Hall

421 Washington Ave, SE

Minneapolis, MN 55455

The Pennsylvania State University (2)

Materials Research Lab

Attn: Della Roy

Rustum Roy

University Park, PA 16802 
DISTRIBUTION (cont):

Princeton University

Dept of Civil Engineering

Attn: George Pinder

Princeton, NJ 08540

RE/SPEC, Inc. (4)

Attn: P. Gnirk

T. Pfeifle

R. Stickney

L. Van Sambeek

PO Box 725

Rapid City, SD 57701

RE/SPEC, Inc (2)

Attn: S. W. Key

D. B. Blankenship

PO Box 14984

Albuquerque, NM 87191

Rockwell International (2)

Rocky Flats Plant

Attn: W. S. Bennett

C. E. Wickland

Golden, CO 80401

US Geological Survey

Special Projects

Attn: R. Snyder

MS954, Box 25046

Denver Federal Center

Denver, CO 80255

US Geological Survey

PO Box 26659

Albuquerque, NM 87125

Woodward-Clyde Consultants (2)

Library Western Region

Attn: Anne T. Harrigan, Librarian Charles Taylor

3 Embarcadero Center, Suite 700

San Francisco, CA 94111

Institut fur Tieflagerung (3)

Attn: K. Kuhn

N. Jockwer

H. Gies

Theodor-Heuss-Strasse 4

D-3300 Braunschweig

FEDERAL REPUBLIC OF GERMANY
Bundesanstalt fur Geowissenschaften und Rohstoffe Attn: Michael Langer

Postfach 510153

3000 Hannover 51

FEDERAL REPUBLIC OF GERMANY

Hahn-Mietner-Institut fur Kernforschung

Attn: Klaus Eckart Maass

Glienicker Strasse 100

1000 Berlin 39

FEDERAL REPUBLIC OF GERMANY

Bundesministerium fur Forschung und Technologie Attn: Rolf-Peter Randl

Postfach 200706

5300 Bonn 2

FEDERAL REPUBLIC OF GERMANY

Physikalisch-Technische Bundesanstalt

Attn: Helmut Rothemeyer

Bundesanstalt 100

3300 Braunschweig

FEDERAL REPUBLIC OF GERMANY

Kernforschung Karlsruhe (3)

Attn: R. Koster

Reinhard Kraemer

K. D. Closs

Postfach 3640

7500 Karlsruhe

FEDERAL REPUBLIC OF GERMANY

Underground Storage of Radioactive Waste

Experimental Programs

Attn: Tuen Deboer, Manager

PO Box 1

1755 ZG Petten

THE NETHERLANDS

Svensk Karnbransleforsorjning AB

Project KBS

Karnbranslesakerhet

Attn: Fred Karlsson

Box 5864

10248 Stockholm

SWEDEN

Ontario Hydro Research Lab

Attn: Dr. D. K. Mukerjee

800 Kipling Ave

Toronto, Ontario

MBZ 554

CANADA 


\section{DISTRIBUTION (cont):}

$\begin{array}{ll}1510 & \text { J. W. Nunziato } \\ 1512 & \text { G. R. Hadley } \\ 1520 & \text { D. J. McCloskey } \\ 1521 & \text { R. D. Krieg } \\ 1521 & \text { H. S. Morgan } \\ 1540 & \text { W. C. Luth } \\ 1542 & \text { B. M. Butcher } \\ 1542 & \text { D. J. Holcomb } \\ 1542 & \text { L. W. Teufel } \\ 1542 & \text { W. R. Wawersik } \\ 1543 & \text { J. L. Krumhansl } \\ 1652 & \text { O. L. George, Jr. } \\ 1820 & \text { R. E. Whan } \\ 1830 & \text { M. J. Davis } \\ 1832 & \text { W. B. Jones } \\ 1832 & \text { J. W. Munford } \\ 1832 & \text { J. A. Van Den Avyle } \\ 1833 & \text { G. A. Knorovsky } \\ 1840 & \text { R. J. Eagan } \\ 1841 & \text { R. B. Diegle } \\ 1841 & \text { N. R. Sorensen } \\ 3310 & \text { W. D. Burnett } \\ 6000 & \text { E. H. Beckner } \\ 6253 & \text { D. A. Northrop } \\ 6253 & \text { A. R. Sattler } \\ 6257 & \text { R. R. Beasley } \\ 6257 & \text { J. K. Linn } \\ 6258 & \text { B. J. Thorne } \\ 6300 & \text { R. W. Lynch } \\ 6310 & \text { T. O. Hunter } \\ 6311 & \text { L. W. Scully } \\ 6312 & \text { F. W. Bingham } \\ 6314 & \text { J. R. Tillerson } \\ 6330 & \text { W. D. Weart } \\ 6331 & \text { A. R. Lappin } \\ 6331 & \text { G. E. Barr } \\ 6331 & \text { S. J. Lambert } \\ 6331 & \text { W. B. Miller } \\ 6331 & \text { K. L. Robinson } \\ 6331 & \text { S. E. Shaffer } \\ 6331 & \text { C. L. Stein (11) } \\ & \end{array}$

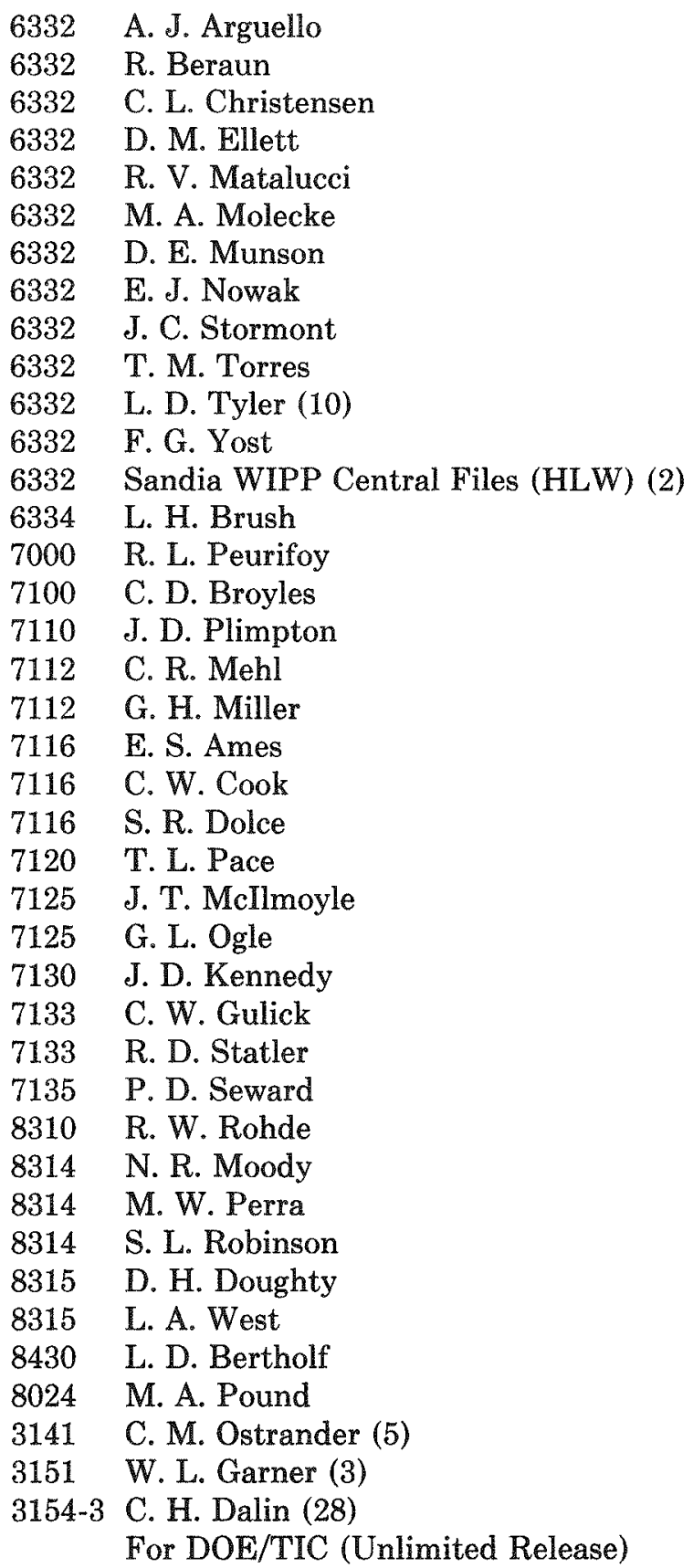

